\title{
A Proposal to Limit the Anti-Competitive Power of Institutional Investors
}

\author{
Eric A. Posner, Fiona Scott Morton, \& E. Glen Weyl*
}

January 29, 2017

\begin{abstract}
Recent scholarship has shown that mutual funds and other institutional investors may cause softer competition among product market rivals because of their significant ownership stakes in competing firms in concentrated industries. However, while calls for litigation against them under Section 7 of the Clayton Act are understandable, private or indiscriminate government litigation could also cause significant disruption to equity markets because of its inherent unpredictability and would fail to eliminate most of the harms from common ownership. To minimize this disruption while achieving competitive conditions in oligopolistic markets, the Department of Justice and the Federal Trade Commission should take the lead by adopting a public enforcement policy of the Clayton Act against institutional investors. We outline such a policy in this article that takes the form of a safe harbor. Investors in firms in welldefined oligopolistic industries must choose either to limit their holdings of an industry to a small stake (no more than $1 \%$ of the total size of the industry) or to hold the shares of only a single "effective firm" per industry. Free-standing index funds that commit to pure passivity would not be limited in size. Investors that violate these restrictions would be exposed to government litigation. Using simulations based on empirical evidence, we show that under broad assumptions this policy would generate large competitive gains while having minimal negative effects on diversification and other values. The policy would also improve corporate governance by institutional investors.
\end{abstract}

\footnotetext{
* Posner is Kirkland \& Ellis Distinguished Service Professor, University of Chicago Law School; Scott Morton is the Theodore Nierenberg Professor of Economics at the Yale School of Management; Weyl is Senior Researcher at Microsoft Research and Visiting Senior Research Scholar at the Yale University Department of Economics and Law School. We thank José Azar, Jonathan Baker, Florian Ederer, Aaron Edlin, Einer Elhauge, Ron Gilson, Scott Hemphill, Doug Melamed, Edward Rock, Steven Salop, Martin Schmalz, and participants at workshops at Columbia Law School and Duke Law School, for comments, and Kathrine Gutierrez and Antonia Woodford for research assistance. Posner thanks the Russell Baker Scholars Fund for financial assistance.
} 
In November 2016 Berkshire Hathaway reported that it bought major stakes in American Airlines, Delta Airlines, and United Continental. Warren Buffett also revealed that it had taken a stake of undisclosed size in Southwest. ${ }^{1}$ These acquisitions fit a pattern. In the last several decades, large institutional investors-including not just Berkshire Hathaway, but BlackRock, Vanguard, Fidelity, and State Street-have adopted an investment strategy of owning a large stake, typically 3-7\%, in competing rivals in a major concentrated industry, like airlines, banking, aluminum, soft drinks, and mobile phones. While making these acquisitions, institutional investors have become the dominant capital market players of our time, displacing dispersed individual investors who now obtain exposure to equity markets through the intermediation of the institutional investors.

Antitrust scholars have long understood that when one owner, whether an investment company or not, acquires large stakes in two or more competitors, it will have an incentive for those competitors to compete less. Recent empirical evidence shows that this type of concentration is in fact leading to higher prices. ${ }^{2}$ Yet antitrust enforcement has not responded to the problem. In this Article, we argue that the concentration of markets through large institutional investors is the major new antitrust challenge of our time. We also propose a simple method, based on existing law, that can address this challenge without causing disruption to capital markets and to industry: limit institutions to a stake of no more than $1 \%$ in more than a single firm in oligopolies.

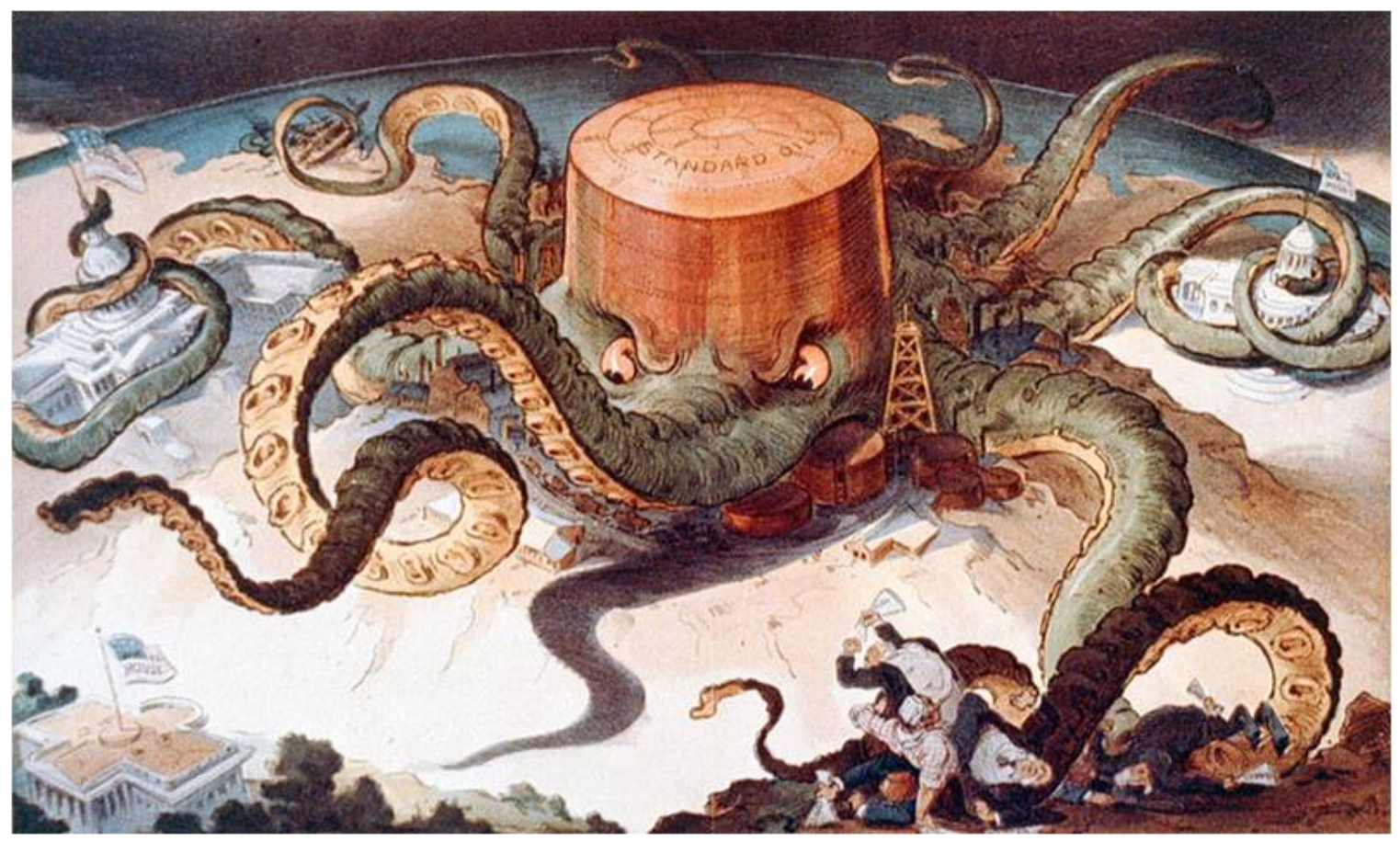

Figure 1: The financially obscured accumulation of political and economic power by "robber barons" was the impetus behind the first American antitrust laws.

\footnotetext{
${ }^{1}$ Doug Cameron \& Nicole Friedman, Warren Buffett's Berkshire Hathaway Discloses New Investments in Airlines, Wall Street Journal, November 14, 2016.

${ }^{2}$ See infra.
} 
First, some history. The impetus for US antitrust law in 1890 was the creation of organizations"trusts" - that bought up and held regional rivals from across the country. John Rockefeller's Standard Oil, often depicted in cartoons of the era as an octopus whose tentacles engulfed markets and state legislatures (see Figure 1), is the most famous example. Other prominent trusts were U. S. Steel and the American Tobacco Company. Congress passed the Sherman Act to forbid (among other behavior) "combinations in restraint of trade." The Justice Department used the law to attack collusion among firms and eventually garnered political support to "bust" the trusts and restore some competition to the US economy.

Following these enforcement actions, however, firms could take the obvious alternative step of simply merging. To block this approach to acquiring market power, in 1914 Congress passed the Clayton Act, which prohibited purchase of stock where "the effect of such acquisition may be substantially to lessen competition ... or tend to create a monopoly of any line of commerce." ${ }^{3}$ When firms evaded the law by purchasing assets rather than stock, Congress amended the Clayton Act in 1950 to include asset purchases as well. ${ }^{4}$ This seemed to do the trick: from roughly 1940 to 1980 the US economy was largely free of large entities whose purpose was to allow a single owner to control competitors and eliminate competition. ${ }^{5}$

However, as this history suggests, antitrust has long relied on regulators playing catch-up with evolving industry practices that tend to eliminate competition. In the absence of such catch-up, there is a natural tendency of innovative financial engineers to find structures that reduce competition without running afoul of the prevailing applications of antitrust law. This is one example of the "red queen" or "policy drift" problem in regulation. ${ }^{6}$ Even when executives do not consciously set out to circumvent the law, competitive forces-paradoxically enough-lead them to chase the highest return on capital, which may involve anticompetitive behavior not necessarily recognized as such. For example, a merger motivated by economies of scale may end up creating conditions for coordinated effects that the merging firms did not anticipate.

The discipline of economics has increasingly been applied to analyze competition and guide the enforcement of US antitrust law during the $20^{\text {th }}$ century. Researchers began to model competition and show how consumers could be harmed or benefited by various types of combinations and competition between firms. Competition among independent firms was of course the basic model. But economists in the 1980s and 1990s also analyzed the idea of "cross-holdings" and joint ventures. These models posited varieties of common ownership structures. The literature included, for example, two product market rivals who owned pieces of each other, two product market rivals who together owned and operated a

\footnotetext{
${ }^{3}$ Clayton Act, $\S 7$ (1914), codified (as amended) in 15 U.S.C. $\S 18$ (2012). Although there is no clearly defined threshold for share acquisitions that lessen competition, acquisitions of less than $25 \%$ but at least $15 \%$ have been judged to be in violation of the Clayton Act. See Steven C. Salop \& Daniel P. O'Brien, Competitive Effects of Partial Ownership: Financial Interest and Corporate Control, 67 Antitrust L.J. 559 (2000).

${ }^{4}$ Celler-Kefauver Antimerger Act (1950).

${ }^{5}$ Einer Elhauge, Horizontal Shareholding, 129 Harv. L. Rev. 1267, 1291-1292 (2016).

${ }^{6}$ Jacob S. Hacker, Privatizing Risk without Privatizing the Welfare State: The Hidden Politics of Social Policy Retrenchment in the United States, 98 Amer. Pol. Sci. Rev. 243 (2004).
} 
third entity, or a common owner of two product market rivals. ${ }^{7}$ The theoretical literature grew significantly during this time. Importantly, the market institutions inspiring the economist authors were these small combinations of one or two firms or interactions among a few firms.

At the same time, however, such combinations were playing a diminishing role in the financial holding structure in the United States. Building on the prescriptions for diversification in early finance theory, in the 1970's an industry of diversified mutual funds and other institutional investors that hold broad portfolios of shares of firms across the economy began to develop. ${ }^{8}$ This development was further stimulated by investor protection regulations that, based on this theory, steered investors towards diversified funds with low costs, which tended to be offered by large institutions that could harness economies of scale. By the 1990's the growth of diversified institutional investing had attracted substantial interest within the academic finance community, which recognized that it could have a dramatic impact on the objectives pursued by firms. ${ }^{910}$ Julio Rotemberg noted, in an unpublished and somewhat neglected paper, that this trend might imply that the diversification, which investors sought through instruments like mutual funds, could lead to widespread joint profit-maximization among firms. ${ }^{11}$ Yet while these developments led to significant concerns about the changing nature of financial capitalism, financial thinkers did not focus on the competition issues directly. ${ }^{12}$

Holdings of index and other mutual funds have grown significantly as a share of the stock market. The success of Fidelity in the 1980s and the popularization of the low-fee index fund by Vanguard in the $21^{\text {st }}$ century are testaments to the efficiency of investing in a diversified, automated

\footnotetext{
${ }^{7}$ Robert J. Reynolds \& Bruce R. Snapp, The Competitive Effects of Partial Equity Interests and Joint Ventures, 4 Inter'I J. Ind. Org. 141 (1986); Friedel Bolle \& Werner Güth, Competition Among Mutually Dependent Sellers, J. Inst'I \& Theoretical Econ. 209 (1992); David Flath, When Is It Rational for Firms to Acquire Silent Interests in Rivals?, 9 Int'l J. Indus. Org. 573 (1991); David Flath, Horizontal Shareholding Interlocks, 13 Managerial \& Decision Econ. 75 (1992); David Reitman, Partial Ownership Arrangements and the Potential for Collusion, J. Industrial Econ. 313 (1994), David Gilo, Yossi Moshe, \& Yossi Spiegel, Partial Cross Ownership and Tacit Collusion, 37 RAND J. Econ. 81 (2006); David Gilo, The Anticompetitive Effects of Passive Investment, 99 Mich. L. Rev. 1 (2000); Salop \& O’Brien, supra; David Malueg, Collusive Behavior and Partial Ownership of Rivals, 10 Int'I J. Indus. Org (1992). Erik Dietzenbacher, Bert Smid \& Bjørnand Volkerink, Horizontal Integration in the Dutch Financial Sector, 18 Int'l J. Indus. Org. 1223 (2000), provides empirical evidence that cross-ownership raises prices and reduces competition. ${ }^{8}$ H. Makower \& J. Marschak, Assets, Prices and Monetary Theory, 5 Economica 261 (1938); Harry Markowitz, Portfolio Selection, 7 J. Fin. 77 (1952); James Tobin, Liquidity Preferences as Behavior Towards Risk, 67 Rev. Econ. Stud. 65 (1958); Paul A. Samuelson, General Proof That Diversification Pays, 2 J. Fin. \& Quantitative Anal. 1 (1967). See also John C. Bogle, Common Sense on Mutual Funds (10 ${ }^{\text {th }}$ ed., 2009).

${ }^{9}$ Robert G. Hansen \& John R. Lott Jr., Externalities and Corporate Objectives in a World with Diversified Shareholder/Consumers, 31 J. Fin. \& Quantitative Anal. 43 (1996).

${ }^{10}$ See Joseph Farrell, Owner-Consumers and Efficiency, 19 Econ. Letters 303 (1985), and Roger H. Gordon, Do Publicly Traded Corporations Act in the Public Interest?, Nat'I Bureau of Econ. Research, Working Paper No. 3303 (1990).

11 Julio J. Rotemberg, Financial Transaction Costs and Industrial Performance, Mass. Inst. of Tech., Alfred P. Sloan Sch. of Mgmt., Working Paper No. 1554-84 (1984). See also Ariel Rubinstein \& Menahem Yaari, The Competitive Market as Cartel Maker: Some Examples, London School of Economics Working Paper 83/84, 1983.

12 Gerald Davis, A New Finance Capitalism? Mutual Funds and Ownership Re-Concentration in the United States, 1 Eur. Management Rev. 5 (2008); Jie He \& Jiekun Huang, Product Market Competition in a World of CrossOwnership: Evidence from Institutional Blockholdings (2014), available at https://papers.ssrn.com/sol3/papers.cfm?abstract_id=2380426.
} 
way. The individual final owner need not pick stocks, nor pay someone else to pick stocks, but rather invests in the whole market and enjoys diversification and low costs. Meanwhile, changes in the lawamong other things, tax law changes that stimulated demand for defined-contribution pensions-and economic conditions encouraged corporations, pension funds, insurance companies, and other large entities to hire asset managers to manage their financial holdings.

The focus of this Article is on "institutional investors," which we define to include mutual funds, index funds, asset managers, and other firms that buy and hold equities on behalf of their investors. Familiar names include Vanguard, BlackRock, State Street, and Fidelity. Recall that a mutual fund is a portfolio of stocks that may have an industry focus (e.g., energy) or a strategy (e.g., growth). By contrast, an index fund holds a portfolio of stocks designed to exactly mimic the index of interest (e.g., S\&P 500). Index fund operations are relatively mechanical, so their costs are low; today they hold probably less than $20 \%$ of the US stock market. ${ }^{13}$ Mutual funds hold about $30 \%$ of the market while all institutional investors together hold about 70\%. ${ }^{14}$ BlackRock, Vanguard, and State Street are not just large, but are often the largest shareholder of major US corporations. ${ }^{15}$ However, there are thousands of small mutual funds, index funds, and other asset managers that comprise about half of stock market holdings.

As these institutions grew, they became important owners of the firms in which they invested. This evolving ownership structure could have had social value because of the benefits it brings to corporate governance. A manager who is also the owner of her firm has no incentive different from the shareholder, because she is the only shareholder. The separation of ownership and control necessary to grow very large companies leads to managers who are not supervised by a knowledgeable monitor, but only by very small individual shareholders who do not have the time, information, or power to oversee management. Institutional investors by contrast, could potentially improve this Berle-Means model of the corporation-featuring widely dispersed ownership by shareholders with tiny stakes - with a large, informed, and incentivized investor. For some commentators, the rise of institutional investors suggested that the agency costs inherent in the management model would be reduced. ${ }^{16}$ They argue

\footnotetext{
${ }^{13}$ We have not found a reliable figure. As of 2010, institutional investors held common stock worth $\$ 11.5$ trillion. Marshall E. Blume and Donald B. Keim, Working Paper, Institutional Investors and Stock Market Liquidity: Trends and Relationships, The Wharton School, University of Pennsylvania (Aug. 21, 2012), available at http://finance.wharton.upenn.edu/ keim/research/ChangingInstitutionPreferences_21Aug2012.pdf, at 20. In the same year, index funds held about $\$ 1.4$ trillion. See Martijn Cremers, Miguel A. Ferreira, Pedro Matos, \& Laura Starks, Indexing and Active Fund Management: International Evidence 36 (unpub. m.s. 2015). This implies that index funds compose $12 \%$ of the market. But index funds have grown considerably in the last few years, so the figure today is somewhat higher.

${ }^{14}$ Blume \& Keim, supra, 4.

${ }^{15}$ “As a consequence of their dominance in the asset management industry, a large and growing number of publicly listed companies in the United States face the Big Three- seen together-as their the largest shareholder...when combined, BlackRock, Vanguard, and State Street constitute the single largest shareholder in at least 40 percent of all listed companies in the United States.... When restricted to the pivotal S\&P 500 stock index, the Big Three combined constitute the largest owner in 438 of the 500 most important American corporations, or roughly in 88 percent of all member firms." P. 17 of Jan Fichtner, Eelke Heemskerk \& Javier Garcia-Bernardo, "Hidden Power of the Big Three? Passive Index Funds, Re-Concentration of Corporate Ownership, and New Financial Risk," available at https://papers.ssrn.com/sol3/papers.cfm?abstract_id=2798653

${ }^{16}$ This view was widespread in the 1990's; see, e.g., Bernard S. Black, Agents Watching Agents: The Promise of Institutional Investor Voice, 39 UCLA L. Rev. 811 (1992); Mark J. Roe, A Political Theory of American Corporate Finance, 91 Colum. L. Rev. 10 (1991). For some early criticisms, see Edward Rock, The Logic and (Uncertain)
} 
that an institution like State Street might hold a significant stake in a firm (by combining holdings across potentially different funds within the institution), and moreover, such a mutual fund had the scale to assign a team of managers to understand the management issues facing that firm and vote the shares accordingly.

The question of whether this happens depends on the nature of corporate governance at this level. There seem to be two different views held by industry participants. One says that institutional investors mostly have a formulaic approach to governance. They ask if the chair and CEO are separate, if the corporation achieved its financial targets, if the right number of directors are independent, and if similar metrics are satisfied. If there is a vote, they are guided by ISS. Such an investor does not seem positioned to influence competition in an industry in the way that concerns us. Of course, neither is such a fund exercising a valuable corporate governance role, so-as we argue below-limiting its stake in any company would have no efficiency consequence.

The other school of thought holds that large investors do a better job of governing top management through voting on members of the board, reviewing and voting on executive compensation, and evaluating the company's broad strategic direction. State Street summarizes this perspective by stating that it follows "a centralized governance and stewardship process covering all discretionary holdings across our global investment centers. This allows us to ensure we speak and act with a single voice and maximize our influence with companies by leveraging the weight of our assets." 17 Vanguard is even more explicit, stating, "We have an experienced team of analysts that independently evaluates each proposal and casts our funds' votes in accordance with the funds' voting guidelines.... our engagement with the directors and managers of the companies in which we invest provides us with the opportunity to target nuanced feedback and messaging more precisely than does voting alone... We believe that our active engagement demonstrates that passive investors don't need to be passive owners." ${ }^{18}$ Recently, Vanguard announced that over the last year it had

conducted over 800 engagements with the management or directors at companies of different types and sizes, encompassing nearly $\$ 1$ trillion in Vanguard fund assets. Our engagement volume represents an increase of $19 \%$ over the previous 12 -month period and $67 \%$ over the past three years. Though we engage with companies for a variety of reasons, we are most likely to engage because we are preparing to vote at the shareholder meeting, an event has occurred at the company that could affect stock value, or our research has uncovered a specific governance concern that is not on the ballot. ${ }^{19}$

\footnotetext{
Significance of Institutional Shareholder Activism, 79 Georgetown L.J. 445 (1990); John C. Coffee, Jr., The SEC and the Institutional Investor: A Half-Time Report, 15 Cardozo L. Rev. 837 (1994).

${ }^{17}$ See Fichtner et al, supra at 10. The quotation is also buried somewhere in State Street's website: https://www.ssga.com/products-capabilities/capabilities/corporate-governance-and-voting-policy.html. ${ }^{18}$ Vanguard, Vanguard's Approach to Corporate Governance, https://about.vanguard.com/vanguard-proxy-voting (accessed November 27, 2016).

${ }^{19}$ Vanguard, Our Engagement Efforts and Proxy Voting: An Update, https://about.vanguard.com/vanguard-proxyvoting/update-on-voting/index.html (accessed November 28, 2016).
} 
Vanguard and other institutional investors have insisted to the press that they take corporate governance seriously. ${ }^{20} \mathrm{~A}$ recent survey of institutional investors found widespread support for this position. $^{21}$

By 2010 the holders of US public equities had changed dramatically. Institutional investors owned $70-80 \%$ of the US stock market, up from $7 \%$ in $1950 .{ }^{22}$ When combined, BlackRock, Vanguard, and State Street constitute the single largest shareholder of at least $40 \%$ of all public companies in the US. They constitute the largest owner in nearly $90 \%$ of public companies in the S\&P 500 , up from $25 \%$ in $2000 .{ }^{23}$ The fraction of US public firms held by institutional investors who simultaneously hold large blocks of other same-industry firms increased from less than $10 \%$ in 1980 to about $60 \%$ in $2010 .{ }^{24}$

José Azar put these pieces of literature together and quantified the size of common ownership links in the economy, thus highlighting the joint implications of these two strands of literature. ${ }^{25}$ Following this work, Azar, Sahil Raina, Martin Schmalz, and Isabel Tecu provided detailed empirical evidence that common institutional shareholdings have already caused higher prices in two US industries. ${ }^{26}$ In careful examinations of the airline and banking industries, they find substantial evidence that prices increase as institutional investors gain larger shares of the firms in an industry, or gain large shares of more of those firms. In aggregate, they find that common holdings raise industry prices by 3$5 \%$ in airlines, though these effects are even stronger when they use an instrumental variables approach to control for confounding factors. In banking, effects are more multidimensional because products are

\footnotetext{
${ }^{20}$ Kirsten Grind \& JoAnn S. Lublin, Vanguard and BlackRock Plan to Get More Assertive With Their Investments, Wall St. J. (March 4, 2015).

21 "The 143 respondents to our survey, mostly very large institutional investors with a long- term focus, indicate that voice, especially when conducted behind the scenes, is highly important. For example, $63 \%$ of the respondents state that, in the past five years, they have engaged in direct discussions with management, and $45 \%$ have had private discussions with a company's board outside of management's presence." Joseph McCahery, Zacharias Sautner, and Laura Starks, Behind the Scenes: The Corporate Governance Preferences of Institutional Investors (2015). This study reported a survey of institutional investors about their role in corporate governance. 22 Joseph A. McCahery, Zacharias Sautner, \& Laura T. Starks, Behind the Scenes: The Corporate Governance Preference of Institutional Investors, J. Fin. (forthcoming 2016), available at http://onlinelibrary.wiley.com/doi/10.1111/jofi.12393/full; Kristian Rydqvist, Joshua Spizman \& Ilya Strebulaev, Government Policy and Ownership of Equity Securities, 111 J. Fin. Econ. 70 (2014); Jan Fichtner, Eelke Heemskerk \& Javier Garcia-Bernardo, Hidden Power of the Big Three? Passive Index Funds, Re-Concentration of Corporate Ownership, and New Financial Risk, CORPNET Working Paper (2016), available at https://papers.ssrn.com/sol3/papers.cfm?abstract_id=2798653.

${ }^{23}$ Fichtner et al, supra; José Azar, Portfolio Diversification, Market Power, and the Theory of the Firm (2016), available at https://papers.ssrn.com/sol3/papers.cfm?abstract id=2811221.

${ }^{24}$ He \& Huang, supra.

${ }^{25}$ Azar first wrote about these issues in his 2012 PhD thesis. See José Azar, A New Look at Oligopoly: Implicit Collusion Through Portfolio Diversification, unpublished Ph.D. dissertation, Princeton University (2012), available at http://www.princeton.edu/ smorris/pdfs/PhD/Azar.pdf. He has since transformed that work into papers including José Azar, Portfolio Diversification, Market Power, and the Theory of the Firm (2016), unpublished manuscript, available at http://dx.doi.org/10.2139/ssrn.2811221 and his joint work mentioned in the next sentence.

${ }^{26}$ José Azar, Martin C. Schmalz, \& Isabel Tecu, Anti-Competitive Effects of Common Ownership, Ross School of Business Paper No. 1235 (2016), available at https://papers.ssrn.com/sol3/papers.cfm?abstract id=2427345; José Azar, Sahil Raina, and Martin Schmalz, Ultimate Ownership and Bank Competition, Ross School of Business Working Paper (2016), available at https://papers.ssrn.com/sol3/papers.cfm?abstract id=2710252.
} 
complicated, but are also substantial relative to other changes in the banking industry during the period they study. Their work indicates that institutional investors are creating a competition problem in industries that are relatively concentrated. ${ }^{27}$

Despite this basic theory being in some ways intuitive and discussed in some form since the 1980 's, it has taken the economics community a long time to process the dramatic scale and potential harms from this behavior. Partially, this was a result of the slow increase in mutual fund prevalence and a lack of understanding of the interaction between institutional investors and firms. Additionally, the economic theory of the problem was long established and therefore an economist could not write about it as a new idea. ${ }^{28}$ However, the real-world changes over the last 100 years have resulted in a difficult situation for policy makers: an apparent conflict between diversified institutional investing and product market competition. This is because we now have ample theory, and growing empirical evidence, that institutional investors who are often considered a benign force in capital markets have reduced competition in some sectors of the US economy. Because of the airline acquisitions mentioned above, the managers of Berkshire Hathaway now exercise corporate control over four competing airlines that comprise more than $80 \%$ of the US airline industry. Berkshire Hathaway will benefit financially from less competition in the US airline industry because less competition will increase share prices.

The tool to counteract anticompetitive investments, the Clayton Act, is of course already in force. Long ago the Supreme Court established the relevant jurisprudence. In United States v. E.I. du Pont de Nemours \& Co., the Court ruled that du Pont's purchase of a substantial stake in General Motors could violate section $7 .{ }^{29}$ "Even when the purchase is solely for investment, the plain language of $\S 7$ contemplates an action at any time the stock is used to bring about, or in attempting to bring about, a substantial lessening of competition." ${ }^{30}$ Section 7 has been used to block numerous mergers and other asset acquisitions of this type over the years, but has generally involved cases like $d u$ Pont, where the firms involved are "operational" companies rather than institutional investors, and so the threat to competition clearer and more direct. ${ }^{31}$

The enforcement problem we address in this Article arises because of the interactive nature of institutional holdings on competition. The investment of one institutional investor in competing firms affects the amount by which another institutional investor "lessens competition" with its investments in the same industry. Thus, a large institutional investor acting unilaterally in the current environment cannot ensure it is not violating the Clayton Act. That is an untenable position for institutional investors,

\footnotetext{
${ }^{27}$ For additional comment on the work by Azar and his colleagues, see John Woodbury, Paper Trail: Working Papers and Recent Scholarship, 14 Antitrust Source 1 (2014); Jonathan B. Baker, Overlapping Financial Investor Ownership, Market Power, and Antitrust Enforcement: My Qualified Agreement with Professor Elhauge, 129 Harv. L. Rev. F. 212 (2016); Peter C. Carstensen, The Philadelphia National Bank Presumption: Merger Analysis in an Unpredictable World, 80 Antitrust L.J. 219, 251 (2015).

${ }^{28}$ Indeed, a model of common ownership by Edgeworth (1881) is cited by Ángel L López \& Xavier Vives, CrossOwnership, R\&D Spillovers, and Antitrust Policy, CESifo Working Paper Series No. 5935 (2016).

29353 U.S. 586 (1957).

30353 at $597-98$.

${ }^{31}$ See, e.g., Fed. Trade Comm'n v. Advocate Health Care Network, No. 16-2492, 2016 WL 6407247 (7th Cir. Oct. 31, 2016); Fed. Trade Comm'n v. Penn State Hershey Med. Ctr., No. 16-2365, 2016 WL 5389289 (3d Cir. Sept. 27, 2016).
} 
who require clarity about where they can legally invest. At the same time, consumers deserve the benefits of competition. We provide a guideline that protects competition at minimal cost to investors.

Two of us argued in a piece written for a popular audience that a possible solution would be to limit the stakes of institutional investors in oligopolistic industries. ${ }^{32}$ We did not, however, work out the exact contours of our proposal, provide a rigorous justification for it, or make clear how it might be implemented or enforced. In this Article, we propose a Clayton Act enforcement policy for institutional investors to be adopted jointly by the Federal Trade Commission (FTC) and United States Department of Justice (DOJ). ${ }^{33}$ The agencies publicly commit to a safe harbor for investors in no more than one firm per industry or with stakes of less than $1 \%$ of the industry. ${ }^{34}$ Other, non-compliant, large investors would remain exposed to agency lawsuits under the Clayton Act. Small investors would remain free to own small stakes in as many firms as they want. Furthermore, there would be no restriction on large holdings across industries provided an institution owned a significant stake in no more than one firm in each industry. This joint agency enforcement policy guideline can be adopted quickly, can be adjusted over time in response to competitive conditions, and is supported by existing law.

Our policy aims to accomplish several objectives, as we discuss in detail in Subsection I.D. We aim for a simple rule that can efficaciously prevent most harm from common ownership while minimally restricting legitimate institutional behavior, and that can be enforced without new legislation in a manner that is predictable to institutions so that they have a clear course of action to avoid liability.

Why not simply propose that regulators and private parties sue institutional investors, as recently advocated by Einer Elhauge? Why is an enforcement policy needed? As Elhauge notes, the legal argument for action seems clear. ${ }^{35}$ Under Section 7 of the Clayton Act, investors are not permitted to buy stakes in companies where "the effect of such an acquisition may be to substantially lessen competition, or to tend to create a monopoly." ${ }^{36}$ As in the case of merger analysis, the plaintiff need not prove that the defendant "intended" to reduce competition; effects are what matter. ${ }^{37}$ Moreover, the so-called passive investment defense in the statute does not apply because institutional investors-even those that engage in "passive" investment strategies-vote and communicate with corporations in an effort to influence their behavior, and are likely to be liable even if they only have the capacity to influence a corporation, whether or not they use it. ${ }^{38}$ Regulators and private antitrust plaintiffs could sue the institutional investors whenever investors' stock purchases tend to lessen competition in particular industries.

But while we agree with Elhauge on the substance of that claim, we argue that guidelines are needed to ensure that such litigation results in good outcomes. In the absence of guidelines, case-bycase litigation would create vast costs and uncertainty, or would be ineffectual, as we illustrate in Subsection I.C. For example, institutions obeying the law at one moment could become liable simply

\footnotetext{
${ }^{32}$ Eric Posner \& E. Glen Weyl, Mutual Funds' Dark Side, Slate, April 16, 2015, http://www.slate.com/articles/news and_politics/view from chicago/2015/04/mutual funds make air travel more expensive institutional investors reduce.html.

${ }^{33}$ We also argue that the rule should be enacted legislatively if the regulatory approach fails. See infra.

${ }^{34}$ We provide a more precise statement of this rule below.

${ }^{35}$ See Elhauge, supra.

${ }^{36} 15$ U.S.C. $\S 18$ (2012).

37 Thus, our argument does not depend on conscious parallelism, as some readers have suggested.

${ }^{38}$ Elhauga, supra at 1305-08.
} 
because other institutions changed their holdings and thereby made an industry less competitive. Institutional investors would need to determine other institutions' ownership shares plus an appropriate definition of hundreds or even thousands of industries to comply with the Clayton Act. Institutional investors have a compelling argument against being forced to operate in an environment where a group of consumers can sue them at any time using a standard that is devised anew each time a complaint is written. Different holdings by different courts would create uncertainty about which investments are legal and which are not. Poor precedent may be created and may hold in some parts of the country while not in other parts. Many lawsuits would result in duplicative legal expenses and delay. This has led commentators to despair of the possibility of addressing these problems. The Economist wrote, "There are no easy fixes.... Limiting the ownership stakes ... would undercut the cheapest and most effective investment strategy available to retail investors." ${ }^{39}$ Yet without a fix, the US economy runs the risk of eventually having every public company held and influenced by a handful of very large institutional investors that gain from less competition.

In this Article, we therefore provide what we feel is necessary public policy: a clear and simple solution to the dilemma posed by The Economist. A policy based on robust economic theory and sound empirics is likely to be successful in court, and therefore reduce uncertainty. Institutions that wish to avoid litigation will know exactly how to do so. Our proposed policy is designed so that the agenciesusing existing guidelines and jurisprudence-would have a strong case against institutions that cause serious competitive harm. Experience suggests that investors would take such an announcement seriously and that the investment industry would move in an organized way to a new procompetitive pattern of holdings. ${ }^{40}$

Under our proposal, institutional investors are limited in their holdings within well-defined oligopolistic industries, defined using conventional standards already used to flag markets of competitive concern. They must either choose to limit their holdings of this industry to small stakes (no more than $1 \%$ of the total size of the industry ${ }^{41}$ ), or they must hold only the shares of a single effective firm (either one firm or many whose total market share equals that of a size-weighted average firm in the industry). Institutional investors would have an additional option: committing to exclusively manage index funds while being purely passive in terms of corporate governance. Investors would reorganize (divest and reinvest) their holdings until they complied with these guidelines. Those who fell into none of these safe harbors would be exposed to agency (and perhaps private) litigation under the antitrust laws.

In the bulk of this Article, we explain how our policy would work and articulate our defense of it. The gains from the policy are clear: it would eliminate anticompetitive behavior which is socially costly. Defenders of institutional investors will argue in response that our policy would prevent valuable diversification and/or exploitation of economies of scale in fund management, which is the main reason that many of these institutions exist in the first place. The key insight on which we rely is that nearly all

\footnotetext{
39 The Economist, Stealth Socialism: Passive Investment Funds Create Headaches for Antitrust Authorities, September 17, 2016.

${ }^{40}$ While we focus on enforcement policy by the DOJ and FTC, we are agnostic as to the form that the policy takes. It could take the form of legislation, for example, or (potentially) a regulation issued by the FTC under $\S 5$ of the Federal Trade Commission Act or a standard courts choose to use to adjudicate cases. See infra.

${ }^{41}$ The $1 \%$ threshold may be too high. We draw it from simulations indicating that competitive harms are unlikely for holdings below this level and quite probable for those above this level; see Subsection I.A. below.
} 
the gains from diversification and all gains from economies of scale can be secured by diversifying across industries, which our proposed policy permits. The gains from within-industry diversification turn out to be trivial. We demonstrate this point with a series of simulations. Moreover, it is much easier to rearrange the financial claims on a flow of profits to maintain competition and efficiency than it is to change the organization of real assets through changing the type of permitted product market mergers. Under our proposal, when product market shares change due to a merger, institutions will have time to adjust their holdings in response and thereby avoid anticompetitive effects. We further show that, based on reasonable assumptions, the social gains from our policy would exceed harms by orders of magnitude. The aggregate size of these gains is large: even with conservative assumptions the gains are a quarter percent of GDP annually, or roughly $\$ 50$ billion.

Because our proposal would require significant change in existing practices, and will thus encounter political resistance, we also examine two other possible solutions. The first solution, which we call the "pure passivity" solution, is for regulators to eliminate all corporate governance roles for funds- including voting on any issue, meeting with executives, etc.- between institutional investors and the firms that they own, so that institutional investors cannot influence firms in any way to reduce competition. While we see a great deal of merit in this approach and allow it as one safe harbor for index funds only, we are concerned that it might interfere with corporate governance by large and sophisticated shareholders and therefore suspect it would not be the more frequently used of our safe harbors.

Another solution we have seen proposed is for the government to get tougher on mergers. The "fewer mergers" solution would require regulators to increase standards for mergers and oppose them when they result in excessive consolidation-considering the likely future stakes of institutional investors. This approach suffers from several problems. First, mergers can generate significant operational benefits which might be blocked from occurring under this policy because of the pattern of institutional holdings. Second, there are many industries that are already concentrated and the antitrust agencies cannot now change their market structure. Third, some industries never pass through a consolidation phase and therefore would not be affected by a "tough merger" policy. Fourth, this policy would likely be ineffective in addressing the problems we are concerned about because a merger of two firms that are already coordinating their prices would not necessarily worsen competition. A merger changes the means of cross-firm coordination rather than its existence and thus controlling mergers would not prevent the harms we seek to prevent.

The Article proceeds as follows. In Part I, we discuss in greater detail the harms we aim to avoid, setting up a quantitative framework for evaluating the type of policy we propose. In Part II we define the policy and use our quantitative framework from Part I to discuss its benefits and costs. On the cost side, we focus on costs from lost diversification but also address the concern that our policy may interfere with corporate governance. We argue that it would in fact improve governance. In Part III, we discuss various alternative approaches. We conclude in Part IV by discussing ways in which our policy, which we argue is conservative, could and might need to be strengthened in the future if it proves insufficient to block significant anticompetitive behavior by institutional investors.

I. Theories of Harm 
Under the Justice Department Horizontal Merger Guidelines ("Guidelines"), the DOJ and FTC evaluate mergers based on their likely effect on competition. ${ }^{42}$ In doing so they consider two types of harms. "Unilateral effects" refer to the incentive of the combined entity to raise price and/or restrict trade based on the assets it then legally controls. "Coordinated effects" refer to the potential for the merger to facilitate a different competitive equilibrium - one that features higher prices or more tacit collusion among the firms remaining in the industry after the merger.

There are several analytical tools the agencies use to carry out merger review, and the Guidelines emphasize that there is no fixed rule or method of analysis. ${ }^{43}$ One tool that is commonly used is the evaluation of market concentration using the Herfindahl-Hirschman Index ("HHI"). ${ }^{44} \mathrm{The} \mathrm{HHI}$ is calculated by adding the squares of the market share of every firm in a market and multiplying by 10,000 . Thus, the maximum possible $\mathrm{HHI}$ is 10,000 , where a single firm owns $100 \%$ of the market. By contrast, a fragmented market consisting of 100 firms with $1 \%$ market share each has an $\mathrm{HHI}$ of 100 . An oligopolistic market with three firms that each possess a third of the industry has $\mathrm{HHI}$ of 3,333 . When two (or more) firms merge, market concentration will change. If two firms in the three-firm market merge, leaving one firm with $67 \%$ of the market and one firm with $33 \%$, the $\mathrm{HHI}$ increases to 5,556 . The increase in market concentration, in this case 2,223 , is designated the $\Delta \mathrm{HHI}$. The regulators impose additional scrutiny on mergers based on the $\triangle \mathrm{HHI}$ and the $\mathrm{HHI}$ of the market after the merger. Since the Philadelphia National Bank decision in 1963, the burden of proof shifts to the merging parties to show the merger is procompetitive when the post-merger market is sufficiently concentrated (the "structural presumption"). ${ }^{45} \mathrm{~A}$ merger is presumptively anticompetitive if $\Delta \mathrm{HHI}>200$ and post-merger $\mathrm{HHI}>$ $2500 .{ }^{46}$

The $\mathrm{HHI}$ approach is rooted in the economic theory of oligopoly, which goes back at least to Cournot. ${ }^{47}$ When a firm in a Cournot oligopoly chooses its output, it faces a tension between increasing revenue by increasing the number of units it sells, and increasing margins by decreasing the number of units it sells. In Cournot's model of $n$ sellers, quantity sold increases, and the oligopoly price declines, as $n$ increases. More firms are better for competition and for consumers, all else equal. In a simple version of Cournot's model the mark-up that can be sustained in the industry over average marginal cost is precisely $\mathrm{HHI} / 10,000$ multiplied by the mark-up a monopolist would choose (the marginal consumer surplus). ${ }^{48}$ This is one theoretical foundation for using the $\mathrm{HHI}$ statistic in competition enforcement; another relates to coordinated effects and derives from the work of Stigler. ${ }^{49}$

\footnotetext{
${ }^{42}$ Based largely on the legal authority of Section 7 of the Clayton Act, codified at 15 U.S.C.A. § 18.

${ }^{43}$ U.S. Dep't of Justice \& Fed. Trade Comm'n, Horizontal Merger Guidelines (2010) [hereinafter 2010 Guidelines].

${ }^{44}$ This index was proposed independently by Albert O. Hirschman, National Power and the Structure of Foreign Trade (1945) and Orris C. Herfindahl in 1950 in his thesis, Concentration in the U.S. Steel Industry. For more on the intellectual history, Albert O. Hirschman, The Paternity of an Index, 54 Am. Econ. Rev. 761 (1964).

${ }^{45}$ United States v. Philadelphia Nat. Bank, 374 U.S. 321 (1963).

${ }^{46} 2010$ Guidelines, supra at 19.

${ }^{47}$ Antoine Augustin Cournot, Researches into the Mathematical Principles of the Theory of Wealth. Trans. N.T. Bacon, New York: Macmillan, 1929.

${ }^{48}$ See, for example, Jean Tirole, The Theory of Industrial Organization (1988).

${ }^{49}$ See George J. Stigler, The Theory of Price (1947).
} 
The $\mathrm{HHI}$ analysis assumes that the firms are independently owned or operated as if they were..$^{50}$ We are interested in the effects of common ownership, and those effects turn out to be quite a bit subtler. In this section, we exposit and clarify the implications of some of the existing theory of unilateral effects of common ownership, discuss how coordinated effects might take place, analyze the implications these conclusions have for the likely outcome of litigation based on this analysis, and then craft a policy based on these factors to achieve our goals.

A. Unilateral Effects

We now consider the theory of unilateral effects of common ownership originally developed by Reynolds and Snapp for a context somewhat different from the one we are concerned with. ${ }^{51}$ They considered the case where one firm (say, GM) purchases shares in a rival (say, Ford) directly. Then when GM raises prices, it recaptures some of the lost demand through former customers who purchase a Ford. This is the classic unilateral effect known as "recapture" in a standard horizontal merger. It does not require any communication. Because GM now owns a share of Ford's profits, GM will benefit more when it increases its prices-even if GM has no influence over Ford. This means that GM has an incentive to raise prices. And this is true even though GM's stake in Ford gives Ford no incentive to reciprocate.

Suppose, more generally, firm i's shareholders own shares of firm i's rivals. If firm $i$ lowers its prices, thereby forcing its rivals to lower prices as well, shareholders of firm $i$ are affected through two pathways: the impact on firm i's profits (which could increase because of the expansion of its market share) and the impact on the rivals' profits (which could decline as they lose market share and/or reduce prices in response). In that sense, the market is more concentrated than the $\mathrm{HHI}$ measure would indicate.

To capture this effect quantitatively, Salop and $\mathrm{O}^{\prime}$ Brien, ${ }^{52}$ building off the work of Bresnahan and Salop on joint ventures, proposed using a modified version of $\mathrm{HHI}$ - or the $\mathrm{MHHI} .{ }^{53}$ The MHHI measures this indirect form of market concentration through common ownership plus the market concentration measured by $\mathrm{HHI}$. The term $\mathrm{MHHI} \Delta$ refers to the difference between $\mathrm{MHHI}$ and $\mathrm{HHI}$, or in other words the portion of market concentration that is due to common ownership. The formula for $\mathrm{MHHI}$ can be rearranged to yield an expression in terms of $\mathrm{HHI}$ and $\mathrm{MHHI}$. We simplify the $\mathrm{MHHI}$ formula slightly by assuming control rights follow ownership rights exactly. That is, a 3\% share of ownership provides a $3 \%$ control right. We do not need a different measure of control in our general setting, and making the two equal renders the model somewhat more intuitive.

The key idea behind $\mathrm{MHHI}$ is that firms maximize the return to their shareholders. Let $\beta_{i j}$ be the fraction of shares in firm $j$ controlled by institutional investor $i$. Assume that these shares are both cash flow shares (the fraction of income of firm $j$ that institution $i$ claims) and control shares in the sense that

\footnotetext{
${ }^{50}$ For example, if management maximizes profits, as may be the case when shareholders own only small stakes both in the firm in question and in its competitors, and management is compensated based on profits or stock price of the firm it controls.

${ }^{51}$ See Reynolds \& Snapp, supra.

${ }^{52}$ Salop \& O'Brien, supra.

${ }^{53}$ Timothy Bresnahan \& Steven C. Salop, Quantifying The Competitive Effects of Production Joint Ventures, 4 Inter'I J. Ind. Org. 155 (1986).
} 
firm $j$ will maximize the weighted sum of the payoffs, call them $\pi_{i}$, of all its shareholders with a weight $\beta_{i j}$ on the payoff of institution $i, \sum_{i} \beta_{i j} \pi_{i} .{ }^{54}$ The payoff to institution $i$ is just the weighted sum, over all firms $j$, of the profits of firm $j \Pi_{j}$ weighted by the shares in $j$ that $i$ controls $\pi_{i}=\sum_{j} \beta_{i j} \Pi_{j}$. Thus, each firm $j$ will maximize $\sum_{i} \beta_{i j} \sum_{k} \beta_{i k} \Pi_{k}$. Note that because these payoffs are measured in absolute dollars rather than being normalized for the size of an institution's total holdings, this analysis implicitly imbeds the intuitive idea that greater attention in aggregate will be paid, for a given ownership share, to the interests of institutions with large total financial interests; we will return to this point below. It implies that the weight firm $j$ will place on its own profit will be the share-weighted average value of $\beta_{i j}$ among $j$ 's shareholders, while the weight it will place on firm $k \neq j$ 's profit will be the share-weighted average value of $\beta_{i k}$ among its shareholders. O'Brien and Salop then study a Cournot model among firms maximizing these objective functions. They show that rather than mark-ups being determined by marginal consumer surplus multiplied by $H H I / 10,000$, it is now determined by $M H H I / 10,000$ where

$$
M H H I=H H I+M H H I \Delta \equiv H H I+\sum_{j} \sum_{k \neq j} s_{j} s_{k}\left(\frac{\sum_{i} \beta_{i j} \beta_{i k}}{\sum_{i} \beta_{i j}^{2}}\right)
$$

where $s_{j}$ is the market share of firm $j .{ }^{55}$

While this formula may appear daunting at first, it elegantly captures several insights about the effects of common ownership. First, common ownership effects rise with the size of the overlapping owners as can be seen in the numerator of the fraction above. More concentrated industries, conditional on ownership structure, have higher common ownership as is reflected by the fact that the first factor in the double sum defining MHHI $\Delta$ is $s_{j} s_{k}$. Second, the degree of competitive concern created by cross-shareholding of firms $j$ and $k$ is proportional to the share-weighted average ownership share in firm $k$ of owners of firm $j$. This is reflected by the numerator in the second factor inside the double sum defining $M H H I \Delta$.

Third, and most subtly, the degree of competitive concern is smaller to the extent that there are large self-owners of firm $j$. A large self-owner of firm $j$ will have, both because of her weight in the firm's calculations and the weight of the value she earns from the firm, a strong interest in ensuring the firm maximizes its own profits. Thus, the formula implies the intuitive idea that small shareholders, even if they are perfectly diversified, are no danger to competition so long as there is some large concentrated shareholder, as the collective action problem among the diversified shareholders, combined with their smaller size, will prevent them from exerting much influence over the firm.

A few examples aid intuition. Consider an oligopolistic industry with four equal-sized firms of $25 \%$ share. The $\mathrm{HHI}$ is 2500 . Suppose the firms' owners are either tiny (so small that they fall out of the expression) or large institutional investors of kinds we now specify. If we give 5 funds equal shares in all firms, the MHHI $\Delta$ is 7500 . Combined with the $\mathrm{HHI}$ of 2500 , this is full monopolization $(10,000)$. The full monopolization result holds whether the shares are $1 \%$ each, $2 \%$, or any other percentage, as long as they are fully diversified. However, such perfect diversification is very unlikely - for one thing management typically owns a stake in the firm - and MHHI $\Delta$ drops drastically with asymmetry. If four of

\footnotetext{
${ }^{54}$ In general, $\mathrm{MHHI}$ can be defined in cases where cash flow rights differ from control rights; we present only this special case as it is the one relevant to us

${ }^{55}$ Salop \& O'Brien, supra at
} 
the funds each takes a stake of $5 \%$ in one of the firms while retaining $1 \%$ in the others, the MHHI $\Delta$ drops from 7500 to 3362 . The MHHI $\Delta$ drops further, to 1658 , if those stakes are $10 \%$ and $1 \%$. If asymmetry is reduced by making the base stakes of the other funds $5 \%$ instead of $1 \%$, then the MHHI $\Delta$ rises back up from 1658 to 6256 because how the holdings look much more like 5 funds investing equally in 4 firms. In the limit, if each fund only owns one firm and no others then there is no overlapping ownership and MHHI $\Delta$ is zero.

We see from this exercise that if there is no or very limited concentrated shareholding in the firm, then even relatively small fully diversified holdings by mutual funds could be highly problematic. In fact, if there is literally no concentrated holding in a firm (an unlikely case as we argue below), then regardless of how small the holdings of each institutional investor are, the theory predicts they achieve the same harms that would accrue to a full merger to monopoly. While this may seem counterintuitive at first, it follows from a very simple logic: someone must determine the firms' goals! That controller is likely to be one of the largest shareholders. If there are no large concentrated shareholders, then the firm will likely be run in the interests of its institutional investors even if these do not individually own very large stakes.

Despite this, some commentators have raised questions about the mechanism by which institutional investors exert influence over the firms they own, regardless of whether it is in their financial interest to do so. Of course, when institutions have incentive and ability to soften competition, it is likely they are finding a way to achieve that. However, we can address the question of what mechanism might be at work. Several possibilities have been proposed in the existing literature and there are many more. For example,

- The institutional investor could advise a CEO on strategy, and explain that profits will increase if the firm raises prices. Since each CEO knows the investor is likely to be talking to rival CEOs, each will guess that his rivals may also raise prices. The CEO gains from raising prices if his rivals are going to do so also - sales remain constant (provided industry elasticity is not too high) and each sale occurs at a higher margin. Thus, the CEO is already incentivized to follow the investor's advice. Moreover, the investor can respond to a CEO who does not follow the investor's advice with adverse votes on his compensation and on the slate of board members.

- The institutional investor could determine that using capacity increases to steal share from rivals will reduce profits. ${ }^{56}$ The investor might make it clear she would vote against the CEO or seek to nominate board members who believe in capacity "discipline" ${ }^{57}$ if the CEO were to carry out a strategy of stealing share.

- The institutional investor could design or promote incentive packages for CEOs to reduce their incentive to compete against rivals. CEOs can be judged by performance relative to competitors or by absolute performance. In the former case, the CEO can do well by taking share from a

\footnotetext{
${ }^{56}$ While a capacity expansion might gain share for the firm that tried it, that share would come at the expense of rival firms in the industry. From the perspective of an investor holding all firms, share changes must net to zero. Schmalz reports a conversation with a fund manager, in which the manager admitted to Schmalz that he does not tell his portfolio firms to compete harder against his other portfolio firms since market share is zero sum. Martin Schmalz, Anti-Competitive Effects of Common Ownership, presentation at Columbia Law School, November 3, 2016.

${ }^{57}$ James Stewart, 'Discipline' for Airlines, Pain for Fliers, N.Y. Times, June 12, 2015, at B1.
} 
rival, for example, regardless of absolute profit levels. In the absolute performance case, taking share from a rival is not rewarded unless it raises absolute profits. Absolute performance compensation promotes softer competition in an oligopoly. Anton et al. show a strong decline in relative compensation with common ownership: more commonly owned firms have compensation practices that systematically discourage aggressive competition. ${ }^{58}$

- The investor could block bids by activist investors interested in aggressive competition. Schmalz provides a case study. ${ }^{59}$

Notice that these effects do not require any communication among rivals in the product market, nor do they require any communication among different investors; they simply involve the direct effects of the common ownership, with all actions taken given this common ownership being legal. Can "passive investors" use these tactics? A passive investment strategy means the institution follows stock-picking strategies like indexing or holding a whole industry rather than actively picking one or two stocks. As our quote in the introduction from Vanguard eloquently states, this has no relationship to whether the institution is a passive owner in the sense of engaging in corporate governance. A truly passive owner would not engage in governance of any kind; it would have zero communication with management and would vote its shares in proportion to other shareholders. It is still likely such an owner would be liable under the Clayton Act if its ownership creates anticompetitive effects. ${ }^{60}$

However, the large institutions we focus on in this article, for example, acknowledge and indeed boast that they communicate with managers ${ }^{61}$ and exercise their votes-indeed, they are required to vote in the best interest of clients ${ }^{62}$-and use these tools to try to improve corporate governance. It is not possible to improve governance without voting and communication with management on topics like compensation, board composition, or strategy. Once communication is ongoing, the tactics above are a natural part of a conversation focused on maximizing shareholder value.

As noted above, full diversification of all shareholders maximizes these harms. In general, however, we expect some stake in the firm to be held by the top management team in the form of stock and stock options (we refer to this stake as the "corporate share")..$^{63}$ It is very unlikely that these top managers will be diversified; they are likely to primarily hold shares in (or can divert income from) the

\footnotetext{
58 Miguel Antón, Florian Ederer, Mireia Giné, \& Martin Schmalz, Common Ownership, Competition, and Top Management Incentives, Ross Sch. of Bus. Paper No. 1328 (2016).

${ }^{59}$ Martin Schmalz, One Big Reason There's So Little Competition Among U.S. Banks, Harvard Business Review Digital Articles (June 13, 2016), https://hbr.org/2016/06/one-big-reason-theres-so-little-competition-among-u-sbanks.

${ }^{60}$ See Elhauge, supra, at _..

${ }^{61}$ See McCahery, et al., supra (63\% of >140 institutional investors surveyed indicated that they had direct discussions with management, and $45 \%$ had private discussions with a company's board outside of management's presence. Long-term investors intervened more intensively than short-term investors); Stephen Choi, Jill Fisch, and Marcel Kahan, Who Calls the Shots?: How Mutual Funds Vote on Director Elections, 3 Harv. Bus. L. Rev. 35 (2013) (describing the pattern of votes by three large mutual funds).

62 Under Department of Labor (in the case of pensions) and SEC regulations. See Department of Labor, Interpretive Bulletin Relating to Written Statements of Investment Policy, Including Proxy Voting Guidelines, 29 CFR 2509.94-2 (2001); Securities and Exchange Commission, Proxy Voting by Investment Advisers, 17 CFR Part 275 (2003), https://www.sec.gov/rules/final/ia-2106.htm\#ruletext.

${ }^{63}$ Or to be effectively controlled by top management given the imperfections in the ability of shareholders to monitor these managers who will then act to maximize their income.
} 
profits of a single firm. Once there is an owner that is not symmetric across firms, the level of ownership by the large institutions affects MHHI $\Delta$.

Fraction of Maximal Harm

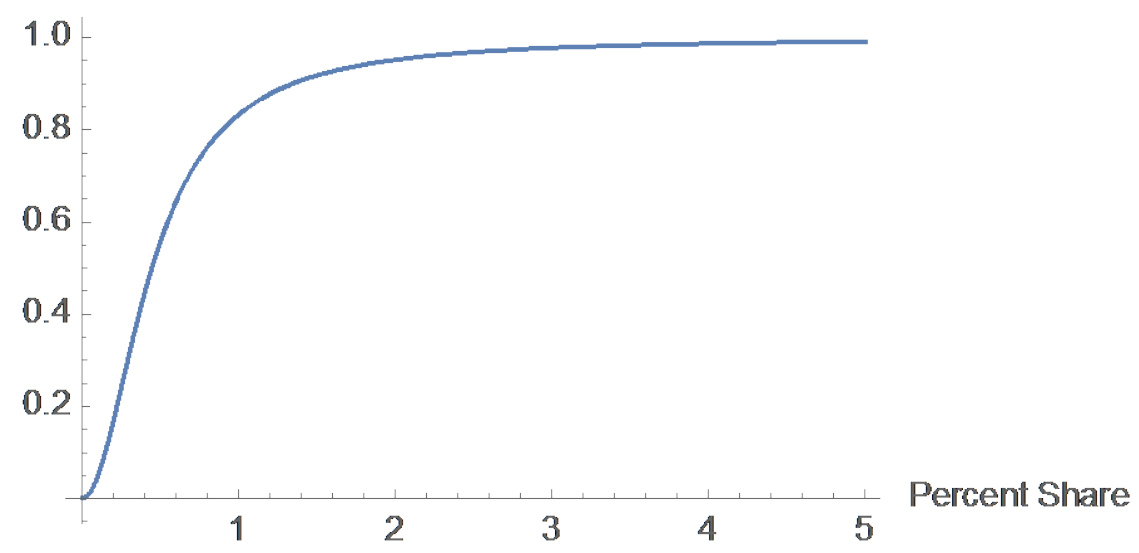

Figure 2: Effect of institutional investor shares on the competitive harm.

Consider an industry with four equal-sized firms where each firm has a manager that controls, in a concentrated manner, $1 \%$ of the firm's equity; and where all other shareholders of the firm that are not institutional investors have extremely small holdings and thus do not exert significant control over the firm. ${ }^{64}$ Now suppose that there are 5 institutional shareholders of equal size with $x \%$ of the shares of all firms. Figure 2 pictures the fraction of the maximal competitive harm (movement to full monopolization) created as a function of $x$. When institutional investors have a very small fraction of the industry, harms are small because the influence of the institutional investors is small relative to the managers. For example, when each institutional investor has a tenth of a percent of each firm, only about $5 \%$ of potential competitive harms are realized, while when each institutional investor has $1 \%$, the clear majority of harms (more than $80 \%$ ) are realized. More generally, the relevant effects are complex; for example, a single very large diversified shareholder is more dangerous than several smaller diversified shareholders even if they have a greater total share.

Of course, these predictions of unilateral effects are based on an extremely specific model of corporate governance and competition. Other models, possibly more realistic ones, might yield different predictions. What reason do we have to take $\mathrm{MHHI}$ as the basis for policy analysis of unilateral effects? The most direct answer would be empirical evidence. This is supplied by the work of Azar, Schmalz, and their co-authors.

Azar, Schmalz, and Tecu study the airline industry. ${ }^{65}$ They examine the relationship across different routes between either $\mathrm{HHI}$ or $\mathrm{MHHI}$ and prices. They use both cross-sectional estimates controlling for a variety of characteristics and changes over time in route composition, competitors, and prices that lead to variety in $\mathrm{MHHI}$ across different routes and over time. They find that the effects of $\mathrm{HHI}$ are essentially the same as those of $\mathrm{MHHI}$ (that is, it does not matter whether $\mathrm{MHHI}$ arises from the MHHIS or HHI; both have similar effects). However, these relationships potentially have substantial

\footnotetext{
${ }^{64}$ Private communication with Miguel Anton. In the US, median insider holdings are $.9 \%$ while median holdings are almost $4 \%$.

${ }^{65}$ See Azar, Schmalz, and Tecu, supra.
} 
endogeneity and mismeasurement. Thus, they employ a natural experiment - a merger of institutional investors - and find that the effects are twice a large using this instrumental variables estimation technique. This suggests that $\mathrm{MHHI}$ is a more reliable indicator of competitiveness than $\mathrm{HHI}$ is.

Azar, Raina, and Schmalz reach an even stronger conclusion in a study of the banking industry. Banks often directly own stakes in one another so they must generalize $\mathrm{MHHI}$ to a broader measure they term GHHI. We do not describe this measure in detail here, but it follows the same logic as $\mathrm{MHHI}$ with an additional layer of holdings added. They find that $\mathrm{HHI}$ has little or no predictive power on the prices and terms of financial products offered by banks, but that GHHI has very strong predictive power on these terms. ${ }^{66}$ One reason is that the GHHI $\Delta$ is negatively correlated with $\mathrm{HHI}$ : in concentrated local markets, banks do not feel the need to have cross-holdings to achieve monopoly profits. Thus, in this case if anything $\mathrm{GHHI}$ seems a more useful measure than $\mathrm{HHI}$ in determining competitive effects. It seems clear that if the Guidelines state the correct $\mathrm{HHI}$ analysis for mergers, then they greatly understate the threat to competition when common ownership exists. This is the motivation for the policy we derive.

A third paper, by Anton and his coauthors, is primarily concerned with CEO incentives, but it also is the first to calculate $\mathrm{MHHI}$ and $\mathrm{MHHI} \Delta$ for the industries with the 2,000 largest public companies in the US. ${ }^{67}$ They show that in construction, manufacturing, finance, and services, the average industry MHHI $\Delta$ has increased by more than 600 points from 1993 to 2014. If investments in mutual funds continue to grow, institutional holdings in oligopolies will necessarily grow, and institutions will have an increasing incentive and ability to soften competition. Therefore, there is good reason to consider what policy might respond to this problem.

\section{B. Coordinated Effects}

One may be concerned that common ownership may facilitate firms' ability to find and sustain a more profitable equilibrium in an industry. These potential harms are usually referred to as "coordinated effects." ${ }^{68}$ Coordinated effects are difficult to model because they are a change in the equilibrium chosen by the oligopoly firms from a more competitive outcome to a less competitive one without any explicit agreement or communication. It is not clear exactly what factors predict increased coordinated effects, and therefore predicting them after a merger is challenging. ${ }^{69}$ Nonetheless, a more concentrated market makes any kind of tacit collusion easier to sustain, and thus the jurisprudence analyzing ordinary horizontal mergers considers harmful coordinated effects to be more likely after a merger. For example, in the 2013 DOJ complaint suing USAirways for acquiring American Airlines (later settled) the Division explained that the three legacy US carriers already held back from vigorous price competition on each other's direct routes. Instead, they priced business tickets on their connecting

\footnotetext{
${ }^{66} \mathrm{Id}$.

${ }^{67}$ See Anton, supra.

${ }^{68}$ See, e.g., Jonathan B. Baker, Mavericks, Mergers and Exclusion: Proving Coordinated Competitive Effects Under the Antitrust Laws, 77 N.Y.U.L. Rev. 135 (2002).

${ }^{69}$ For recent contributions to this literature, see William E. Kovacic, Robert C. Marshall, Leslie M. Marx, \& Steven P. Schulenberg, Quantitative Analysis of Coordinated Effects, 76 Antitrust L.J. 397 (2009); Helder Vasconcelos, Tacit Collusion, Cost Asymmetries, and Mergers, 36 Rand J. Econ. 39 (2005); Olivier Compte, Frédéric Jenny, \& Patrick Rey, Capacity Constraints, Mergers and Collusion, 46 Eur. Econ. Rev. 1 (2002).
} 
flights at the same price as the business ticket on their competitor's direct flight. USAirways, by contrast, had an aggressive discounting program for connecting business flights and therefore was the only source of price competition for business travelers. ${ }^{70}$ The complaint explains that the existing practice of "respecting the nonstop" is the coordinated conduct that worries competition authorities, and that the merger of USAirways and American would exacerbate it. ${ }^{71}$ The loss of the small amount of existing price competition would be an increase in "coordinated effects."

Courts have acknowledged the dangers of coordinated effects when mergers concentrate an industry. In U.S. v. Philadelphia National Bank, ${ }^{72}$ the Supreme Court blocked the merger of two banks because the merger would have significantly concentrated the market and the banks could not provide clear evidence that the merger would not have had anticompetitive effects. The Court rejected the banks' efforts to prove that the merger would increase access to credit, noting that a merger "is not saved because, on some ultimate reckoning of social or economic debits and credits, it may be deemed beneficial." ${ }^{73}$ In Hospital Corporation of America v. FTC, ${ }^{74}$ the Seventh Circuit agreed with the FTC that the purchase of two hospitals by a third in a market of eleven raised significant dangers of coordinated effects. While the court hinted that the concentration of the market alone might have justified an injunction of the merger, it also noted other factors that would facilitate coordination including the Hospital Corporation's control over management of two firms and a tradition of cooperation among the hospitals in the market. ${ }^{75}$ More recently, in FTC v. H.J. Heinz ${ }^{76}$ the D.C. Circuit held that the FTC established a prima facie case that a merger in the baby food industry would create what it called "interdependent anticompetitive conduct." "77 Lower courts have also carefully analyzed the market conditions that would be created by a merger and taken into account the risk a merger would eliminate a particularly aggressive competitor (sometimes called a "maverick"), traditions of cooperation in the market, and cost structures and other factors that make it hard or easy for the remaining firms to detect cheating. ${ }^{78}$

The bottom line is that courts are receptive to arguments that when a merger would significantly concentrate an industry, it is anticompetitive because of the risk of coordinated effects; in addition, many courts have been quite skeptical of defendants' efforts to show that such mergers have efficiencies that would more than offset the harms. ${ }^{79}$ This is true even though defendants typically have

70 13-cv-01236 United States v US Airways Group (2013) pp4-5

${ }^{71}$ Ibid. paragraph 46

72374 U.S. 321 (1963).

73 Id. at 371.

${ }^{74} 807$ F.2d 1381 (7th Cir. 1986).

${ }^{75}$ Id. at 1389.

${ }^{76}$ F.T.C. v. H.J. Heinz, 246 F.3d 708 (D.C. Cir. 2001).

77 Id. at 716.

${ }^{78}$ See, e.g., United States v. H \& R Block, Inc., 833 F. Supp. 2d 36, 79-81 (D.D.C. 2011); F.T.C. v. CCC Holdings Inc., 605 F. Supp. 2d 26, 60=67 (D.D.C. 2009).

${ }^{79}$ Some commentators see a trend in the other direction. See, e.g., Kovacic et al., supra, at 405 \& n. 27, citing FTC v. Arch Coal, Inc., 329 F. Supp. 2 d 109 (D.D.C. 2004); Airtours v. Commission, Case T-342/99, 2002 E.C.R. 11-2585 (Ct. First Instance). We are not persuaded. Indeed, conceivably, the government could rely on an older line of cases, including Brown Shoe Co. v. United States, 370 U.S. 294 (1962); United States v. Aluminum Co. of America, 377 U.S. 271 (1964); United States v. Von's Grocery Co., 384 U.S. 270, and United States v. Pabst Brewing Co., 384 U.S. 546 (1966), which "seemed, taken as a group, to establish the illegality of any nontrivial acquisition of a 
a number of possible arguments available to them, e.g. possible economies of scale or improved technology use. By contrast, in the institutional investor setting, the efficiency defenses available to institutions that have taken significant stakes in multiple firms in an oligopolistic industry are weak. We therefore believe that courts will be even more receptive to arguments that the acquisition of such stakes is illegal. ${ }^{80}$

One important reason for courts' receptivity to arguments based on market concentration even when the danger of coordinated effects is hard to quantify is that even when a merger does not end up causing prices to rise, it can lay the groundwork for further concentration of the industry. In the words of the Supreme Court,

A fundamental purpose of amending $\S 7$ was to arrest the trend toward concentration, the tendency to monopoly, before the consumer's alternatives disappeared through merger, and that purpose would be ill-served if the law stayed its hand until 10, or 20, or 30 more Philadelphia banks were absorbed. ${ }^{81}$

This argument applies with extra force to institutional investment, which may significantly concentrate the market through quite incremental acquisitions, and which exhibits a significant decades-long trend toward such concentration. We return to this point below.

We note that institutional owners who have legitimate reasons to speak and discuss business details with top management of many firms in an industry may use this position to create or promote illegal agreements among competitors. That type of communication is a violation of Section 1 of the Sherman Act and is not the focus of this article. ${ }^{82}$ We are interested in the case where competition is harmed without the sort of illegal agreement that violates the Sherman Act. That said, we want to ensure that any policy we recommend also limits the potential harm that investors, while performing their legitimate governance activities, can coordinate the "conspiracy against the public" that Adam Smith famously warned against.

C. Implications for Litigation

The most natural solution to these harms is to simply enforce Section 7 of the Clayton Act, accounting for effects through $\mathrm{MHHI}$ and coordinated effects enabled by common ownership. ${ }^{83}$

competitor, whether or not the acquisition was likely either to bring about or shore up collusive or oligopoly pricing. The elimination of a significant rival was thought by itself to infringe the complex of social and economic values conceived by a majority of the Court to inform the statutory words 'may ... substantially ... lessen competition.' ... None of these decisions has been overruled." Hosp. Corp. of Am. v. F.T.C., 807 F.2d 1381, 1385 (7th Cir. 1986).

${ }^{80}$ As argued by Elhauge as well, see Elhauge, supra.

81 United States v. Philadelphia Nat. Bank, 374 U.S. 321, 367 (1963).

82 It is also possible that that jointly governing a firm may allow for competing funds to collude with each other. This is an interesting potential harm, but not one we try to address.

${ }^{83} \mathrm{~A}$ separate legal argument could be based on section 8 of the Clayton Act, 15 U.S.C. § 19 (2012), if institutional investors frequently place their directors, officers, or other employees on the boards of firms in which they own significant stakes. While we have heard some anecdotal evidence of this practice, we have been unable to ascertain whether it is common. (One reason why it may not be common: if an institutional investor benefits from non-public information, it would be barred from trading.) If it is a common practice, or if an argument can be made 
Ultimately we agree with this conclusion, but we are concerned that, absent clear guidelines for when such cases would or would not be brought, such litigation could lead to a combination of chaos and stasis. In this subsection, we use simulations to illustrate some of the difficulties plaintiffs, institutional investors, and courts would face without further guidance.

An initial problem is that it is not even clear what standard a court would use to determine liability. Without guidance from regulators, a court may not even use an MHHI threshold; even if it did, it would not necessarily choose the threshold that other courts used. Normal case-by-case adjudication would most likely result in a range of different rules, standards, and approaches. ${ }^{84}$ But to fix ideas imagine, for example, that courts found liable any institutional investor whose holdings increased $\mathrm{MHHI}$ by 200 points relative to the counterfactual of the investor not being in the industry at all; other natural counterfactuals can be used to reach similar conclusions to what follows. ${ }^{85}$ We now illustrate some of the cases that could succeed under such a standard:

1. Suppose that there is an industry with four symmetric firms (so that even without common ownership the industry has $\mathrm{MHHI}$ of 2500) and that each has a large concentrated shareholder with $15 \%$ of the stock. Each also has a CEO who holds $0.1 \%$ of equity. There is also a single moderate-sized fully diversified shareholder with $2 \%$ holdings in each firm and no one else owns a non-trivial fraction of the stock. In such a setting $\mathrm{MHHI}$ is 130 because the $15 \%$ concentrated holdings are sufficient to block the importance of the $2 \%$ diversified holder. It seems unlikely a suit against the $2 \%$ holder could succeed.

However, now suppose that one of the $15 \%$ concentrated holders faces financial distress and is forced to liquidate its holdings. The MHHIS then jumps to almost 2000. If the $2 \%$ diversified holder were forced to sells its holding, the MHHI $\Delta$ would fall to 0 . Thus, after the concentrated holder exits, a possible antitrust case could be made against the $2 \%$ holder. One can see here that an institution that was initially not liable would in this case become liable purely based on the behavior (exit from the industry) of another institution. This would make it very hard for institutions to plan their activities to confirm to the law.

2. Consider the same symmetric four-firm industry and suppose again that there are (roughly as at present and as we discuss further in the next section) managers of each

that directors or officers of some corporations are controlled by institutional investors, a possible argument can be made that section 8 is implicated, although the statute has rarely been invoked in the past and never, as far as we know, against an institutional investor. For a case providing support for this theory, see Reading Intern., Inc. v. Oaktree Capital Management LLC, 317 F. Supp. 2d 301 (S.D.N.Y. 2003) (holding that an asset management firm violated section 8 by placing its president on the board of a firm in which it held a stake and a principal on the board of a competitor in which it also held a stake). Other legal theories are also available, depending on the facts; for example, if the managers of the operational firms know that investors intend for them to reduce competition and acquiesce in their instructions, liability could be found under section 1 or 2 of the Sherman Act.

${ }^{84}$ Or to put the argument as simply as possible: if you believe that the DOJ and FTC acted properly by establishing $\mathrm{HHI}$ rules in the 2010 Guidelines rather than leaving merger standards entirely to judicial development, then you should believe that they should establish $\mathrm{MHHI}$ rules as well.

85 This seems to be Elhauge's view, though he also seems to stipulate that the MHHI for the industry must be at least 2500 and he also seems to use current holdings as a baseline rather than counterfactual holdings as we do. Elhauge, supra at 1303. 
firm with $1 \%$ concentrated holdings and five diversified institutions holding respectively $6 \%, 5 \%, 4 \%, 3 \%$ and $2 \%$ of the industry. (By "diversified institution," we mean a firm with a stake in every firm in the industry.) The MHHID is huge in this case: 7420 , almost fully monopolizing the industry. The question now is which institution could/should have liability? The unilateral divestiture of holdings by any of the institutions barely budges $\mathrm{MHHI}$ : even if the $6 \%$ institution exits, $\mathrm{MHHI}$ falls by less than 100 points. Exit of the $2 \%$ institution reduces $\mathrm{MHHI}$ by only 4 points. Institutions might play a game of "chicken," waiting for the others to sell their holdings so that the last institution is no longer causing a significant increase in $\mathrm{MHHI}$ and can maintain its investments. In this case, which we think is common in current US data, MHHID is a "collective responsibility" of the holding pattern. It would be very difficult for institutions to protect themselves in this case also; an aggressive court might hold all liable. But what are the limits of this collective responsibility? How small would an institution have to be to avoid it? These questions would make investment planning challenging.

3. A third issue concerns market definition. Suppose that a product market such as premium groceries is a tight oligopoly of four publicly traded firms. On the other hand, suppose the market for groceries broadly is diffuse and has many privately-held companies, so that even if all publicly traded grocers were to merge this would not cause significant competitive concern in the market for groceries. Would an institution that held all premium grocers be liable under the Clayton Act? On the one hand, it could not have any effect on the market for groceries more broadly as it faces so many privately held competitors. On the other hand, a private suit might succeed against it based on the narrower market definition, but it would be very hard for the institution to predict whether this is the case or not.

Of course, issues like this arise all the time in standard merger review, but a standard merger is a single, large decision made by a pair of corporations. Institutional investors constantly acquire and sell equities, and so must worry continuously about falling out of compliance with the Clayton Act. An institution trying to comply with the Clayton Act would have to sort out these issues in hundreds or thousands of industries, even if it held only a small and fully diversified holding. Without some centralized process of determining market definitions of concern, institutions would find it extremely challenging to comply with the law.

4. Finally, consider an industry composed of four equally-sized firms where the only nontrivial sized holding is by a single fully diversified institution holding only $0.2 \%$ of the shares in that industry and by the managers who hold $1 \%$ concentrated in each firm. In

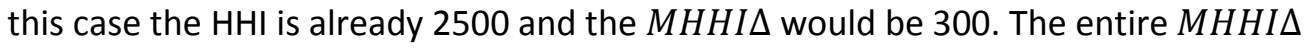
would be eliminated by the diversified institution exiting the industry. Such an institution would clearly be liable. However, it seems hard to imagine such an institution having a significant impact on competition in the industry. Managers are likely to have enough control to disregard most of the investor's power in corporate governance and ensure profit maximization. By the same token, this power is so small that it is unlikely to enable the institution to participate in corporate governance. If it refrained from doing so, it is hard to imagine it being desirable to force it to exit. Yet it would be liable under the definition above. 
Of course, the outcome we mention above is only one of many that a decentralized process led by courts and plaintiffs could eventually settle on. We do not mean to predict that it would be the final standard that would emerge; courts might recognize the issues above and navigate them in a way that did not create the liability we fear above. However, other standards that might emerge could be equally problematic and worst of all would be if no standard emerged of any sort, with different courts making different, case-by-case judgments. In the latter case, there would be little an institutional investor could do to stay on the right side of the law.

Yet just as troubling is the opposite possibility. Courts might become apprehensive about the set of issues we raise above and carve out broad exemptions that would allow all or nearly all the status quo harms to continue. Consider the following example:

1. Suppose courts were to decide that a firm could be liable only if the unilateral MHHI reduction - given current holdings - caused by the firm entirely exiting the industry exceeded 200 points. ${ }^{86}$ In this case, as highlighted above, very few institutions would be liable at present. Given that the MHHID is already thousands of points in many industries (see Anton et al. 2016 for a comprehensive survey), this would allow the persistence of enormous harms of a quarter percent of GDP based on our calculations in II.E below.

2. Suppose that courts decided that any existing holdings are too hard to unscramble and only find against additional marginal acquisitions that sufficiently increased $\mathrm{MHHI}$. This would clearly allow for the persistence of status quo harms. Furthermore, it is hard to imagine how such a standard could prevent the situation worsening. Suppose that Vanguard gradually receives an inward flow of funds over many years causing it to grow, with all holdings perfectly diversified. This could gradually fully monopolize many industries. At what point, could a suit against Vanguard succeed? All increased holdings would be gradual and incremental and in any given year $\mathrm{MHHI}$ might not increase by more than a few points.

3. Suppose that the courts decided that either extremely narrow or extremely broad market definitions were appropriate. In either of these cases, very few if any harms would create liability.

We do not highlight these problems to promote despair; we do believe there exist standards consistent with reasonable interpretations of existing antitrust laws that would be workable and effective. However, it seems extremely unlikely that without clear thought and guidance that a decentralized process of litigation will happen upon such guidelines in the medium term. ${ }^{87}$ In the next subsection, we aim, through simulation examples, to construct a simple such interpretation.

\footnotetext{
${ }^{86}$ As noted, this may be Elhauge's view; see id.

${ }^{87}$ We suspect that the sorts of worries mentioned above might also cause courts to demand a higher standard of proof than they do in the context of merger challenges. For example, they might require stronger empirical showings of harm rather than (as in the merger context) just the possibility of competitive harm, which is assumed to follow almost automatically from sufficient market concentration; or they might require stronger showings of knowledge or intention on the part of decisionmakers. For related concerns, see Baker, supra. Yet another possible argument on behalf of institutional investors is that many of them are composed of separate legal entities with
} 


\section{Effects of Potential Policies}

As highlighted above, $\mathrm{MHHI}$ is far higher than $\mathrm{HHI}$ in many oligopolistic industries and appears to have substantial anticompetitive effects. Azar, Raina, and Schmalz find that GHHI is roughly 1400 points, or two-thirds greater than HHI. ${ }^{88}$ Azar, Schmalz, and Tecu find that, depending on the level of aggregation, $\mathrm{MHHI}$ on average airline routes exceeds $\mathrm{HHI}$ by $1600-1700$ points, or more than a third. ${ }^{89}$ These effects are large and there is now empirical evidence suggesting these changes in effective concentration have detrimental competitive effects. We aim to design a policy to guide enforcement of the antitrust laws that would combat these effects. In doing so, we aim for five principles: simplicity, minimalism, efficacy, enforceability, and predictability. We now briefly describe these principles and then explore simulations that help us identify a policy that meets these criteria.

By simplicity we mean that we seek a policy that can be described briefly and understood easily. By minimalism we mean a policy that is only restrictive to the degree that it needs to be to achieve its other goals. By efficacy we mean a policy that seems likely to eliminate most significant competitive harms, both unilateral and coordinated. By enforceability we mean a policy which, if violated, will likely give the DOJ and/or FTC grounds for bringing a case against a firm violating that policy and an expectation of prevailing in court. By predictability we mean a policy under which institutions subject to the policy would have a clear sense of reasonable actions that they could take that would protect them from liability. ${ }^{90}$ These concerns led us to the following general outline: Safe harbors should be given for sufficiently small institutions and for holdings in industries that do not raise clear competitive concerns. In industries that do raise competitive concerns, large enough institutions must "concentrate their holdings" in a way we define below.

We now define the thresholds for industries of competitive concern, the size of the institutions restricted, and actions necessary for sufficient concentration. In the remainder of this section we use simulations to tie down a reasonable set of parameters that satisfy these requirements. We do not pretend to have developed an optimal policy, any more than is the case at present with the current standard Horizontal Merger Guidelines. In fact, our goal of simplicity requires us to choose thresholds that are round and policies that are natural rather than fully optimal.

First, which industries should cause us concern? The traditional threshold that the DOJ and FTC use for markets that are "highly concentrated" and thus trigger the highest antitrust scrutiny is an $\mathrm{HHI}$ more than 2500. This guideline forms a useful starting place for developing a list of oligopolistic industries for which common ownership raises significant antitrust concerns. A major conceptual issue to clarify is the difference between a "relevant market," the unit of analysis in an antitrust case, and an industry, which could be broader, such as a collection of related markets. The eventual litigation of the common ownership violation will occur under existing jurisprudence and law: it will be won because of

\footnotetext{
separate boards of directors. While we doubt that such formal separation would make a difference for antitrust analysis, see, e.g., Sunkist Growers, Inc. v. Winckler \& Smith Citrus Products Co., 370 U.S. 19 (1962) (disregarding separation of legal entities which had common owners), it might give rise to problems of proof in some instances. ${ }^{88}$ Azar, Raina, and Schmalz, supra.

${ }^{89}$ Azar, Schmalz, and Tecu, supra.

90 These sorts of concerns are familiar from the law and economics literature on rules and standards. See, e.g., Daniel A. Crane, Rules Versus Standards in Antitrust Adjudication, 64 Wash. \& Lee L. Rev. 49 (2007); and, more generally, Louis Kaplow, Rules versus Standards: An Economic Analysis, 42 Duke L.J. 557 (1992).
} 
anticompetitive effects in relevant antitrust markets. However, the list that will be useful to institutional investors as they plan their holdings is not one of relevant antitrust markets (e.g. gasoline retailing in greater Cincinnati), but rather industries that can be mapped to companies that sell in relevant markets belonging to that industry. Of course, this mapping is not perfectly clean. However, if the agencies use broad principles and their discretion, and begin conservatively, the perfect need not be the enemy of the good. For example, relevant airline markets are often defined as city pairs. The agencies can analyze competition at the city pair level and observe that the biggest four airlines compete in concentrated markets throughout the country. This would lead the agencies to place "the airline industry" on the list along with measured market shares for all competitors. Suppose another industry has a relevant market in it that is highly concentrated but many others that are not. The agencies might determine that common ownership of the competing firms in the industry was not yet harmful to competition and not place it on the list. The DOJ and FTC should use their discretion to consider other factors such as those listed below that may cause common ownership to be anticompetitive in that setting. We emphasize, however, that they should, and we believe will, only use discretion based on these factors when they believe the competitive effects are likely to be large relative to the harms of limiting diversification:

1. A single $\mathrm{HHI}$ for an industry must inherently be aggregated. If an industry is national in scope, the $\mathrm{HHI}$ will be calculated using national market shares. Alternatively, the $\mathrm{HHI}$ might be defined in terms of a local geographic market where firms compete, and summarized at a national level. Many industries are only modestly concentrated at an aggregate level but may be extremely concentrated in local markets, in which case an appropriate national summary HHI would be some aggregate of the local market HHIs. For example, at a national level the airline industry is only moderately concentrated, but many routes are extremely concentrated.

2. Significant harms may arise not just from reduction of competition in consumer product markets but also in the market for inputs to the firms' production, such as labor markets or other elements of the supply chain. The boundaries of such markets may not line up perfectly with the boundaries of the product markets. Recent evidence suggests that market power in labor markets may be as large a drag on economic growth, and as great a source of inequality, as is product market power. ${ }^{91}$

3. Some industries may have a relatively low $\mathrm{HHI}$ but an extremely high $\mathrm{MHHI}$ due to unusual patterns of institutional holdings. Such industries may be of competitive concern. For example, consider an industry with 10 firms each with equal market share. Such an industry has an $\mathrm{HHI}$ of 1000 and thus would not usually be of competitive concern. However, suppose that, as is quite plausible at the status quo, all firms in the industry are controlled overwhelmingly by fully diversified institutional investors. This would lead to very high $\mathrm{MHHI}$; if these institutional investors are fully diversified and there are no other non-trivially sized investors $\mathrm{MHHI}$ would equal 10000 indicating full monopolization of the industry! While perfect diversification and a complete lack of concentrated holdings by other investors may be relatively uncommon, the DOJ and FTC should be vigilant about patterns like this and consider them for inclusion on the list of oligopolies even if $\mathrm{HHI}$ is not above 2500.

\footnotetext{
${ }^{91}$ Council of Economic Advisers Issue Brief, Labor Market Monopsony: Trends, Consequences, and Policy Responses (October 2016), available at https://www.whitehouse.gov/sites/default/files/page/files/20161025_monopsony_labor_mrkt_cea.pdf.
} 
4. If a firm participates in more than one oligopoly, an institution would have to make its holdings consistent with the policy across industries; for example, if Delta Airlines were to buy Coca-Cola, an institution owning the joined entity would not be able to own major competitors in either the airline or soft drink industries.

5. Defining markets and industries requires judgment and cannot be reduced to a mechanical rule. For example, the boundaries of markets in the high-tech sector are notoriously fluid and therefore the agencies would have discretion to define markets per current competitive conditions.

We propose that the DOJ and FTC would annually compile a list of industries to be designated as "oligopolies" based primarily on the $\mathrm{HHI}$ of these industries exceeding 2500 , but also considering the factors listed above. For example, the Horizontal Merger Guidelines state that moderately concentrated industries, those in the 1500-2500 range, may be of competitive concern. If other competitive factors warranted, such an industry could be classified as an oligopoly. We recommend that the agencies state that the oligopoly list is solely for enforcing investor ownership of competitors and has no legal force in other settings such as merger analysis. As we argue below, there is no cost to industry participants and a very small cost to investors from classifying an industry as an oligopoly; moreover, institutional investors prefer stability. Therefore, over-classification may be desirable.

The creation of this list may be a substantial effort if the agencies attempt to exhaustively analyze every industry in the United States at one time. If resources are limited, our recommendation is to begin the list with industries where there is empirical evidence of competition problems due to common ownership or other clear empirical evidence of concentration. As different types of evidence accumulate over time, more industries can be added to the list at annual intervals. We defer discussion of finer details of our proposal to the next section. We also do not discuss the safe harbor of "pure passivity" that we offer as an option to firms that exclusively offer index funds (index funds currently constitute a relatively small portion of total institutional investing) until Subsection III.A as we believe such truly passive firms would have little or no effect on firm policies and thus can be treated as if they were among the miniscule holders our analyses below effectively ignore.

The purpose of the policy should be to force huge institutional investors with large holdings within industries to "undiversify" within each industry-or as we will put it, to "concentrate" their holdings within a small number of firms within each industry. A first question is: in how many firms within an industry should an institutional investor be allowed to own stakes? Given that most of the industries of concern will have an $\mathrm{HHI}$ of 2500 or above, none will have more than four significant-sized firms. It is thus implausible that an institutional investor should be allowed to hold significant stakes in three or four significant firms. The question then is whether it should be allowed to hold significant stakes in two firms, or just one, or perhaps one (or two) plus several small firms outside the four-firm core. Thus, the only way to achieve significant concentration of holdings is to restrict institutions to holding either roughly a single or roughly two firms in an industry. We are also concerned about investors' ability to enable coordinated effects in a concentrated industry. ${ }^{92}$ For this reason, and for simplicity, if an institution has a significant investment in one large firm it is not allowed to additionally own small holdings in other firms in the same industry.

\footnotetext{
${ }^{92}$ See Subsection I.B., supra.
} 
Because the natural limiting case where it would be most plausible to allow holding significant stakes in two large firms is when there are four equally-sized firms, we conducted our simulations primarily in this case. We assume a $1 \%$ concentrated management holding in each firm. Azar and Schmalz report that a common pattern of holdings for the top five institutional investors is for the largest institution to have roughly $6 \%$ ownership, the next $5 \%$, etc..$^{93}$ We simplify this structure and assume all institutional investors are of size $4 \%$ for our simulations in Table 1 . We assume that after following the policy, institutional investors would maintain the same aggregate dollar holding in the industry but simply rearrange which firms they hold.

We consider two possible policies. The first would allow institutions to hold two firms in the industry and the second would allow them to hold only one. To evaluate the first (two-firm) option, we need (in theory) to consider the many ways in which five institutional investors could hold four firms in combinations of two. Fortunately, the simulations reveal that the different combinations yield similar results, and so for simplicity we can present a few scenarios. In all these scenarios, holdings are chosen to be as even across firms as possible given the constraints. In the first scenario, "cyclic," institutional investors hold in a cyclic pattern; one institution holds firm $A$ and $B$, another $B$ and $C$, another $C$ and $D$, etc. In the second scenario, "divide," institutions divide up the firms in the market: some hold $A$ and $B$, others $C$ and $D .{ }^{94}$ Matters are simpler with only a single firm being held by each institution as there is only one symmetry-maximizing pattern ${ }^{95}$ consistent with this. However, we emphasize that essentially any pattern of holdings consistent with the policy yields similar qualitative conclusions.

The baseline we describe has the following attributes, detailed in Table 1. In the laissez faire setting (row 1), no policy is followed and the MHHID is at an exceptionally high level of 7407 . The next two rows show that under the two-firm policy, the improvement in competition-while real-is not sufficient. The cyclic scenario yields an MHHI $\Delta$ of 1860, comparable to the levels that Azar, Schmalz and Tecu find at present in most airline routes. The divide scenario is even worse, yielding an $M H H I \Delta$ near 2500. By contrast, the one-firm policy generates an MHHI $\Delta$ of 0 . We thus reject the two-firm policy.

However, many oligopolistic industries feature some small players alongside the dominant firms. We want to ensure our policy allows institutional investors to own stakes in these smaller firms even when those institutional investors also own a large stake in a large firm; otherwise, our policy would disadvantage small firms in their pursuit of capital. This leads us to the concept of an "effective firm" which we defer to the next section.

\section{TABLE 1: Testing One- or Two-Firm Holding Policies \\ Market and investor structure:}

4 firms with $25 \%$ share each; $\mathrm{HHI}=2500$

Each firm has a manager with a $1 \%$ concentrated ownership stake

5 large funds looking to hold $4 \%$ of total industry (e.g., $4 \%$ of 4 firms, $8 \%$ of 2 , or $16 \%$ of 1 )

\footnotetext{
93 See Azar, Schmalz and Tecu, supra.

94 We mean "divide" in a manner coordinated only through market prices, such as through the fact that asset prices for firms without large investments are likely to be lower relative to fundamental value thereby encouraging investments by other institutional investors. We do not mean conscious or explicitly coordinated division. ${ }^{95}$ By this we mean that holdings by institutional investors are as uniform as possible across firms, so that the degree to which one firm has stronger holdings by institutional investors in aggregate is minimized.
} 


\begin{tabular}{|c|c|c|c|c|}
\hline \multicolumn{2}{|r|}{ Setting } & \multirow{2}{*}{$\begin{array}{l}\text { Fund holdings } \\
\text { in each firm } \\
4 \% \\
\end{array}$} & \multirow{2}{*}{$\begin{array}{l}\text { MHHIS } \\
7407 \\
\end{array}$} & \multirow{2}{*}{$\begin{array}{r}\text { MHHID vs. } \\
\text { laissez faire } \\
\qquad \mathrm{N} / a\end{array}$} \\
\hline Laissez faire & $\begin{array}{l}\text { Each fund holds equal stake in all } \\
\text { firms }\end{array}$ & & & \\
\hline $\begin{array}{l}\text { Funds own two } \\
\text { firms }\end{array}$ & $\begin{array}{l}\text { Each fund holds } 2 \text { firms in cyclic } \\
\text { pattern: fund } 1 \text { holds firms A \& B, } \\
\text { fund } 2 \text { holds firms B \& C, etc. }\end{array}$ & $8 \%$ & 1860 & -5547 \\
\hline $\begin{array}{l}\text { Funds own two } \\
\text { firms }\end{array}$ & $\begin{array}{l}\text { Funds "divide" their holdings: } 3 \\
\text { funds hold firms A \& B, and } 2 \text { funds } \\
\text { hold firms C \& D }\end{array}$ & $8 \%$ & 2484 & -4923 \\
\hline $\begin{array}{l}\text { Funds own one } \\
\text { firm }\end{array}$ & Funds only hold a stake in one firm & $16 \%$ & 0 & -7407 \\
\hline
\end{tabular}

The analysis so far suggests that our policy should prohibit institutional investors from owning stakes in more than one firm in an oligopolistic industry. But a possible response is that some institutional investors will have a strong interest in diversifying within an industry, and if their stake in each firm is small enough, such investors do not pose a threat to competition. Accordingly, we now seek to determine a threshold level of (per-firm) ownership below which an institutional investor may own as many firms as it wants within an industry.

We think a plausible such threshold is $1 \%$. Imagine that the five institutional investors each own $1 \%$ of each of the four firms and there are no concentrated holdings beyond the managers. Then MHHID is $80 \%$ of full monopolization. However, given that most of the largest five institutions currently hold $2 \%$ or more of most large firms, unless these institutions choose to break themselves up en masse, it seems unlikely that they would all end up choosing the option to hold $1 \%$ of each firm. They are likely to want to invest more in one firm (e.g., four times the original symmetric holdings in 4 firms) to keep the dollar level of investment in the industry constant. The large funds' desire to hold more than the threshold percentage in the industry generates the asymmetry that is so important to lowering $\mathrm{MHHI}$ and stimulating competition. For this reason, $1 \%$ is a simple and plausible threshold. We must ensure, however, that such a policy would be efficacious, in the sense that it is likely to avoid most harms from common ownership, and minimal, in the sense that there is not a more permissive policy that would accomplish the same goal.

To analyze this question, we consider a more realistic variant on the simplified scenarios in Table 1 ; we must add this additional complexity as it helps us determine whether our chosen threshold is both efficacious and minimal. We suppose that the 5 large institutional investors have symmetric shares of $6 \%, 5 \%, 4 \%, 3 \%$ and $2 \%$ respectively in all firms in our above-posited industry with four equally-sized firms. A pattern roughly like this is common in many industries as we illustrate in our appendix. Furthermore, in addition to these large institutions, we include five small institutional investors, each with a $1 \%$ stake fully diversified within the industry; we also assume that each firm has a $1 \%$ concentrated management stake. Our results inevitably depend on precisely which of the large institutions holds which of the firms, but they are fairly robust across these; we report results based on the arrangement that is "maximally balanced" in the sense that the large institutional investors' share holdings are as even as possible across firms. 
Table 2 shows our results. If the $1 \%$ policy is enforced and institutions maintain the dollar level of investment in the industry, the MHHID falls to 119 points (row 2). This is still non-trivial, but seems a reasonable level that can be tolerated in the interests of simplicity. This suggests the $1 \%$ level would be efficacious. However, could we raise this threshold significantly without causing large problems? To analyze this question, we consider two scenarios. First, suppose the threshold were raised to $2 \%$, allowing the $2 \%$ institutional investor to maintain full diversification. In this case the MHHID rises to 243 points, which seems too high to allow given the limited benefit. Second, consider raising the threshold to $1.5 \%$ and suppose that the $1 \%$ funds all expand to this maximal level. This causes the MHHID to rise to 261 . Again, this seems too much to allow for a miniscule benefit and a less round number. Thus, we conclude that $1 \%$ is a reasonable, minimal, and efficacious threshold.

TABLE 2: Percent Diversified Holding Threshold

\section{Market and investor structure:}

4 firms with $25 \%$ share each; $\mathrm{HHI}=2500$

Each firm has a manager with a $1 \%$ concentrated ownership stake 5 large funds looking to hold respectively $6 \%, 5 \%, 4 \%, 3 \%$ and $2 \%$ of the industry

5 small funds hold $1 \%$ fully diversified in the industry

\begin{tabular}{|c|c|c|c|c|}
\hline \multicolumn{2}{|r|}{ Setting } & Fund holdings & MHHID & MHHI $\Delta$ vs. \\
\hline Laissez faire & Each fund holds equal stake in all firms & $\begin{array}{r}6 \%, 5 \%, 4 \% \\
3 \%, 2 \%, 51 \% \\
\end{array}$ & 7421 & $\mathrm{~N} / \mathrm{a}$ \\
\hline $\begin{array}{l}1 \% \text { threshold } \\
\text { for small fund } \\
\text { exception }\end{array}$ & $\begin{array}{l}\text { Large funds hold stakes concentrated } \\
\text { in a single firm ( } 3 \% \text { and } 2 \% \text { fund } \\
\text { overlap), small funds remain } \\
\text { diversified }\end{array}$ & $\begin{array}{r}24 \%, 20 \%, \\
16 \%, 12 \%, 8 \%, \\
51 \% \\
\text { diversified }\end{array}$ & 119 & -7302 \\
\hline $\begin{array}{l}2 \% \text { threshold; } \\
2 \% \text { funds } \\
\text { diversified }\end{array}$ & $\begin{array}{l}\text { Large funds hold stakes concentrated } \\
\text { in a single firm, small funds and } 2 \% \\
\text { fund remain diversified }\end{array}$ & $\begin{array}{r}24 \%, 20 \%, \\
16 \%, 12 \%, 2 \% \\
\text { and } 51 \% \\
\text { diversified } \\
\end{array}$ & 243 & -7179 \\
\hline $\begin{array}{l}1.5 \% \\
\text { threshold; } 1 \% \\
\text { funds grow to } \\
1.5 \%\end{array}$ & $\begin{array}{l}\text { Large funds hold stakes concentrated } \\
\text { in a single firm ( } 3 \% \text { and } 2 \% \text { fund } \\
\text { overlap), small funds diversified and } \\
\text { hold } 1.5 \% \text { each }\end{array}$ & $\begin{array}{r}24 \%, 20 \%, \\
16 \%, 12 \%, 8 \% \\
\text { and } 51.5 \% \\
\text { diversified }\end{array}$ & 261 & -7160 \\
\hline
\end{tabular}

However, we also want to make sure that the threshold we choose will minimize the risk of coordinated effects. Given that, as noted above, the top five institutional investors usually hold $2 \%$ or more, it seems likely that top management of the firms would want to be in regular contact with them concerning strategic direction, and not with a $1 \%$ shareholder in the firm. The Securities and Exchange Commission reached a similar conclusion in $\mathbf{2 0 1 0}$ when it issued a rule allowing owners with at least a 
$3 \%$ stake to nominate directors. ${ }^{96}$ We thus considered it safe from the perspective of coordinated effects to allow institutional investors with stakes below $1 \%$ to hold in a diversified manner (that is, diversified within, as well as across, industries). ${ }^{97}$

Now we turn to the enforcement policy to be applied to institutional investors holding large stakes in competitors. Because our solution to the common ownership problem is primarily to enforce an existing law, the Clayton Act, it is critical that a persuasive case could be brought and won against most institutional investors attempting to violate our policy. This requires articulating the grounds for such an action and the quantitative case that could be made establishing that these grounds hold. In what remains of this section, we investigate these latter two questions quantitatively. First, we consider whether moving away from the status quo to our policy significantly increases competition. Second, we ask whether acquiring a stake above a $1 \%$ threshold generates competitive harms of significant magnitudes relative to a case when the policy is followed. In both cases, we calculate MHHI $\Delta$ as one element to making a strong case against institutional investors violating our policy.

To conduct the first exercise, we continue with our simulation framework from Table 1 (though again we considered a variety of similar settings that yield comparable conclusions) in Table 3 . We thus return to the assumption of five large institutional investors with stakes of $4 \%$. To comply with our policy, these institutional investors must hold a single effective firm in an oligopoly. However, we also assume the five small fully diversified institutional investors with $1 \%$ each diversified holdings in the full industry as in Table 2.

In this setting, could the DOJ and FTC win Clayton Act cases brought against firms violating our policy? The critical and different feature of this analysis-unlike the traditional case of a regular acquisition-is the necessity of defining the "but-for" world. This forms the counterfactual legally permissible set of holdings against which the holdings are claimed to "substantially lessen competition, or tend to create a monopoly." Throughout we focus on the counterfactual most closely associated with our policy: that the firm would hold the same aggregate stake, but in a concentrated manner in a single firm. We focus on the change in MHHIS. In each scenario, we assume that all shares moving between the relevant holdings in the case and the counterfactual are effectuated by selling to or buying from very small holders who contribute a de minimis amount to $\mathrm{MHHI}$ and corporate governance. ${ }^{98}$

First, we ask whether such cases would succeed, starting from laissez faire fully diversified holdings like those at present, against the median firm with $4 \%$ symmetric holdings. In laissez faire with such holdings, the MHHID is 7421 points (Table 3, row 1 ), which comes extremely close to fully monopolizing the industry. Suppose the enforcement agencies pursue a case against one of the large institutional investors. If it complied with our policy (concentrated its holdings into a single firm), this

\footnotetext{
${ }^{96}$ This was the proxy access rule, later vacated by D.C. Circuit based on general concerns that the rule did not pass a cost-benefit analysis. See Business Roundtable v. SEC, 647 F.3d 1144 (D.C. Cir. 2011).

${ }^{97}$ One might worry that investors with $1 \%$ or so would have the ear of CEOs, and thus could help coordinate behavior. If this turns out to be true, the threshold could be lowered and/or limits could be put on communications between investors and management.

${ }^{98}$ Obviously, if the shares were sold to another large institution, the desired reduction in concentration would not occur.
} 
would reduce the MHHID by 1471 points, down to $5941 .{ }^{99}$ Given this dramatic reduction in MHHI from this move, it seems very likely a case against an institutional investor would succeed. This case could be made based on the counterfactual of following our policy but also relative to many other counterfactuals. For example, if the court considered the counterfactual of the investor divesting all holdings but those in a single firm (row 3), this would still reduce MHHI by 372 points. In row 4, we consider the full effect of our policy, which causes each institutional investor to hold only one firm in the industry at $16 \%$. MHHID falls drastically to 125 .

As O'Brien and Salop argue, it is well-established in case law that firms cannot avoid Clayton Act liability simply by gradually accumulating partial stakes in multiple firms. ${ }^{100}$ However, it is an interesting enforcement question to ask at what point does the increase in concentration show up as quantitatively large enough to make a successful case likely? To investigate this, we consider enforcement against a violation of our policy beginning from a state of compliance shown as the "status quo: all funds in safe harbor." In this benchmark the MHHID is 125 (row 4). We then consider the case that can be made if investors deviate from status quo. If a single investor increases her holdings by putting a $1 \%$ stake into another firm (row 5), this would raise $\mathrm{MHHI}$ by 58 . While such a small change in MHHI may at first sight seem insufficient to support a lawsuit, we note, in row 6 , that if all institutional investors acted in this way, $\mathrm{MHHI}$ would increase by 323. A court would have to decide between enforcing the instant case or waiting a few months for the exact same case to reappear, with many funds and a larger harm, and rule at that point. Courts and the agencies would use their discretion as to how each wants to spend judicial and prosecutorial resources in such a case. We see that the threat of enforcement at the laissez-faire status quo may be sufficient to move the equilibrium away from the extreme harms found at present and would also be sufficient to enforce a regime in which all institutional investors followed the policy.

\section{TABLE 3: Result of deviations from safe harbor in market with 4 equal-sized firms}

\section{Market and investor structure:}

4 firms with $25 \%$ share each. $\mathrm{HHI}=2500$

Each firm has a manager with a $1 \%$ concentrated ownership stake.

5 large institutional investors and 5 small fully diversified institutional

investors (holding $1 \%$ in all firms)

\begin{tabular}{|c|c|c|c|}
\hline \multicolumn{2}{|r|}{ Setting } & \multirow{2}{*}{$\begin{array}{r}\text { MHHI } \\
\\
7413 \\
\end{array}$} & \multirow{2}{*}{$\begin{array}{c}\text { MHHID vs. } \\
\text { status quo } \\
\\
n / a \\
\end{array}$} \\
\hline $\begin{array}{l}\text { Status quo: Laissez- } \\
\text { faire }\end{array}$ & $\begin{array}{l}\text { Each large fund holds } 4 \% \text { in all } \\
\text { firms }\end{array}$ & & \\
\hline $\begin{array}{l}\text { One fund in safe } \\
\text { harbor }\end{array}$ & $\begin{array}{l}\text { One large fund concentrates } \\
\text { holding, holding } 16 \% \text { in one firm }\end{array}$ & 5941 & -1472 \\
\hline $\begin{array}{l}\text { One fund reduces } \\
\text { holdings to single firm }\end{array}$ & $\begin{array}{l}\text { One large fund sells holdings in } \\
\text { all but a single firm }\end{array}$ & 7049 & -372 \\
\hline
\end{tabular}

\footnotetext{
99 The last institution to comply would also lower $M H H I \Delta$ by a large amount.

100 Salop and O'Brien, supra at 565.
} 


\begin{tabular}{|l|l|r|r|}
$\begin{array}{l}\text { Status quo: All funds } \\
\text { in safe harbor }\end{array}$ & $\begin{array}{l}\text { All large funds hold 16\% in one } \\
\text { firm }\end{array}$ & 125 & n/a \\
\hline $\begin{array}{l}\text { One fund deviates } \\
\text { slightly from safe } \\
\text { harbor }\end{array}$ & $\begin{array}{l}\text { One large fund acquires 1\% stake } \\
\text { in a second firm, in addition to its } \\
16 \% \text { stake }\end{array}$ & 183 & 58 \\
\hline All funds deviate & $\begin{array}{l}\text { All large funds acquire a 1\% stake } \\
\text { in a second firm }\end{array}$ & 448 & 323 \\
\hline
\end{tabular}

We continue in Tables 4 and 5 to analyze different product market structures. These results are presented to show robustness; they do not change the basic findings. Table 4 presents the results for a duopoly. Row 1 shows that MHHI $\Delta$ is 4942, while $\mathrm{HHI}$ is 5000 in a two-firm industry with equal shares; thus, $\mathrm{MHHI}$ is 9942, nearly the maximum. Row 2 shows the impact of a single institutional investor coming into compliance-MHHI falls by 1190. Row 3 shows the dramatic impact of all five funds coming into compliance-MHHI falls by 4786 relative to laissez faire. Row 4 shows that even a very small increase in cross-holdings by one institutional investor in violation of our policy increases $\mathrm{MHHI}$ by more than 200 points. In the asymmetric market structure, we see that one institutional investor moves $\mathrm{MHHI}$ by a worrisome amount; but more important, when all institutional investors violate the policy, $\mathrm{MHHI}$ rises by more than 1200 points (row 5). Under an MHHI standard, courts should find that even minor deviations from the policy lead to a substantial lessening of competition.

TABLE 4: Result of deviations from safe harbor in duopoly market

2 firms with $50 \%$ share each. $\mathrm{HHI}=5000$

Each firm has a manager with a $1 \%$ concentrated ownership stake 5 large funds and 5 small funds (small funds have $1 \%$ in all firms)

\begin{tabular}{|c|c|c|c|}
\hline \multicolumn{2}{|r|}{ Setting } & \multirow{2}{*}{$\begin{array}{r}\text { MHHID } \\
\\
4942 \\
\end{array}$} & \multirow{2}{*}{$\begin{array}{l}\text { MHHID vs. status } \\
\text { quo } \\
\\
\mathrm{N} / \mathrm{c}\end{array}$} \\
\hline $\begin{array}{l}\text { Status quo : laissez } \\
\text { faire }\end{array}$ & $\begin{array}{l}\text { Each large fund holds } 4 \% \text { in all } \\
\text { firms }\end{array}$ & & \\
\hline $\begin{array}{l}\text { One fund in safe } \\
\text { harbor }\end{array}$ & $\begin{array}{l}\text { One large fund concentrates } \\
\text { holding, holding } 8 \% \text { in one firm }\end{array}$ & 3752 & -1190 \\
\hline $\begin{array}{l}\text { Status quo: All } \\
\text { funds in safe } \\
\text { harbor }\end{array}$ & $\begin{array}{l}\text { All large funds hold } 8 \% \text { in one } \\
\text { firm }\end{array}$ & 156 & -4786 \\
\hline $\begin{array}{l}\text { One fund deviates } \\
\text { slightly from safe } \\
\text { harbor }\end{array}$ & $\begin{array}{l}\text { One large fund acquires } 1 \% \text { stake } \\
\text { in a second firm, in addition to its } \\
8 \% \text { stake }\end{array}$ & 405 & 249 \\
\hline All funds deviate & $\begin{array}{l}\text { All large funds acquire a } 1 \% \text { stake } \\
\text { in a second firm }\end{array}$ & 1384 & 1228 \\
\hline
\end{tabular}

TABLE 5: Result of deviations from safe harbor in a market with 2 big and 4 small firms 
2 firms with $34 \%$ share each, 4 firms with $8 \% . \mathrm{HHI}=2568$. Effective firm $=0.257$

Each firm has a manager with a $1 \%$ concentrated ownership stake

5 large funds and 5 small funds (small funds have $1 \%$ in all firms)

\begin{tabular}{|c|c|c|c|}
\hline \multicolumn{2}{|r|}{ Setting } & \multirow{2}{*}{$\begin{array}{r}\text { MHHID } \\
7346 \\
\end{array}$} & \multirow{2}{*}{$\begin{array}{l}\text { MHHID vs. status } \\
\text { quo } \\
\\
\mathrm{N} / \mathrm{a}\end{array}$} \\
\hline $\begin{array}{l}\text { Status quo: laissez } \\
\text { faire }\end{array}$ & $\begin{array}{l}\text { Each large fund holds } 4 \% \text { in all } \\
\text { firms }\end{array}$ & & \\
\hline $\begin{array}{l}\text { One fund in safe } \\
\text { harbor }\end{array}$ & $\begin{array}{l}\text { One large fund holds } 11.7 \% \text { in } \\
\text { one large firm }\end{array}$ & 5862 & -1484 \\
\hline $\begin{array}{l}\text { Status quo: All } \\
\text { funds in safe } \\
\text { harbor }\end{array}$ & $\begin{array}{l}2 \text { large funds hold } 11.7 \% \text { in one } \\
\text { large firm each, } 3 \text { large funds } \\
\text { hold } 17 \% \text { in one small firm each }\end{array}$ & 808 & -6538 \\
\hline $\begin{array}{l}\text { One fund deviates } \\
\text { slightly from safe } \\
\text { harbor }\end{array}$ & $\begin{array}{l}\text { One large fund with investment } \\
\text { in a large firm invests } 1 \% \text { in } \\
\text { second large firm }\end{array}$ & 996 & 188 \\
\hline $\begin{array}{l}\text { One fund deviates } \\
\text { slightly from safe } \\
\text { harbor }\end{array}$ & $\begin{array}{l}\text { One large fund with investment } \\
\text { in a small firm invests } 1 \% \text { in a } \\
\text { large firm }\end{array}$ & 855 & 47 \\
\hline $\begin{array}{l}\text { All funds deviate } \\
\text { from safe harbor }\end{array}$ & $\begin{array}{l}\text { Each fund invests } 1 \% \text { in one large } \\
\text { firm in addition to their original } \\
\text { investment }\end{array}$ & 1320 & 512 \\
\hline $\begin{array}{l}\text { All funds deviate } \\
\text { from safe harbor }\end{array}$ & $\begin{array}{l}\text { Each fund invests } 1 \% \text { in another } \\
\text { firm of opposite size from what } \\
\text { they originally invested in }\end{array}$ & 1015 & 207 \\
\hline
\end{tabular}

Table 5 provides the case of 6 firms where two are large and 4 relatively small. Again, in this representative case, we see that our policy significantly reduces $\mathrm{MHHI}$ (rows 2-3), and that the policy is robust in the sense that even minor deviations would run afoul of section 7 of the Clayton Act (rows 4$6)$.

As we have emphasized above, the change in MHHI $\Delta$ depends on the existing pattern of holdings among institutional investors and the counterfactual the court and the agencies use. We have attempted to select what we think are intuitive and simple counterfactuals to analyze. While others could be chosen, there is no reason that they would be more empirically plausible than the ones we use here given how easy it is for an institutional investor to buy and sell shares, and how often it occurs.

A possible response to our argument is that it wrongly assumes that courts would enforce the antitrust laws against an institutional investor that makes a "slight deviation" that increases MHHI $\Delta$ only 
by a small amount (47 in the example in Table 5). One might imagine an institutional investor arguing that it is unfair to hold it liable for such a small change in concentration.

The problem with this argument is that the magnitude of the MHHI $\Delta$ increase is not important. Because the social gain when an institutional investor deviates from our policy is effectively nil, the fact that $\mathrm{MHHI \Delta}$ increases a tiny rather than a huge amount is no defense, especially given that the first deviation could pave the way for incremental deviations by other institutional investors that in aggregate result in a large social cost. In this sense, the $\mathrm{HHI}$ analogy for traditional horizontal mergers can be misleading. The justification for a large $\Delta \mathrm{HHI}$ threshold is that operational mergers frequently generate efficiencies because of economies of scale. The Guidelines tolerate the risk that a series of incremental mergers could lead to excessive market concentration because a low $\Delta H H I$ would block too many efficient transactions. There is no corresponding justification for incremental within-industry common ownership, as we have explained. A large $\Delta H H I$ threshold also limits the extent to which costly divestiture in one sector is needed to enable a merger between firms that achieve significant efficiencies in other sectors. By contrast, because financial claims on real assets do not involve the sorts of sunk investments that traditional mergers do, institutional investors can easily rearrange their holdings to maintain compliance with our policy while the market changes around them.

Conceivably, the government could also pursue a litigation strategy in which it waited for several institutional investors to acquire small stakes and then sue all of them, while pointing out to the court (or courts) the multiplicative effect of the institutions' independent behavior. Note that, even if the eventual outcome were uncertain, the benefit an institutional investor would derive by holding a small amount above a clearly-defined red-line that would trigger enforcement action and likely reputational harm, would be very small. We thus suspect it would be feasible to maintain the policy in practice. Importantly, in terms of practical consideration in bringing such a Clayton Act case, unlike a standard horizontal merger, there is essentially no efficiency rationale for allowing cross-holding by institutional investors. ${ }^{101}$ With these tools and the existing evidence of harm, we feel the DOJ and FTC could credibly commit to enforcement at the new status quo, which we now describe in detail.

\section{Our Proposed Policy}

We now fully state our policy and discuss a range of its potential effects, beyond addressing the core competitive concerns that led us to the policy in the previous section.

\section{A. Full Statement}

We begin by stating our policy, which depends on several terms that themselves need to be operationalized (in italics).

No institutional investor or individual holding shares of more than a single effective firm in an oligopoly may ultimately own more than $1 \%$ of the market share.

We now define the terms above.

\footnotetext{
${ }^{101}$ As discussed infra.
} 
- An institutional investor is said to hold or be invested in the set of firms representing the aggregate holdings of the entire investment company reporting to or under the corporate control of the same firm. Different "institutions" run by the same management company are treated as part of the same set of holdings and whenever we refer to an "institution," a "fund," or an "institutional investor," we mean the broad fund holding company (e.g., Vanguard, BlackRock, Fidelity, etc.), not the specific fund offered by these companies (e.g., Vanguard S\&P 500 Admiral Shares).

- An institutional investor is invested in more than a single effective firm if it is invested in more than one firm, and the total market share of all firms it holds any stake in is greater than $H H I / 10000$ in the oligopoly. (Note that this will be the average market share in the industry. For example, a 4-firm symmetric industry has an $\mathrm{HHI}$ of 2500 , so a single effective firm is $25 \%$ of the market.) The effective firm definition allows an institutional investor to hold multiple competing sufficiently small fringe firms instead of a large firm.

- Prior to the start of each calendar year, the DOJ and FTC would make a list of industries constituting oligopolies and company market shares based on the standards discussed in Subsection I.C above. There would be some mechanism to solicit comments from any interested parties. The DOJ and FTC would then finalize the list with at least a month before the beginning of the new year to allow the institutional investors time to rearrange their holdings to comply with the policy.

- The market share ultimately owned by an institution or individual $i$ is the sum over all firms $j$ of the product of the share that institution has in that firm $\beta_{i j}$ and the market share of firm $s_{j}: \sum_{j} \beta_{i j} s_{j}$.

- The top managers or directors of firms are their board of directors and managers whose compensation is required to be disclosed by the Securities and Exchange Commission.

While we have generally assumed that our policy should take the form of an enforcement policy issued by the DOJ and the FTC, analogous to the merger guidelines, there are other possible approaches. It is possible that the FTC could issue formal rules under $\S 5$ of the FTC Act. ${ }^{102}$ In addition, the policy could be enacted as legislation. There are different advantages to each of the approaches. The DOJ and FTC could adopt an enforcement guideline at their discretion, while a regulation would require noticeand-comment rulemaking and be subject to judicial review under the Administrative Procedure Act, and legislation would require an act of Congress. Thus, it would be easiest to put in place an enforcement guideline, relatively difficult to issue a regulation, and (we suspect) nearly impossible to enact legislation, at least in the near term. However, the major disadvantage of an enforcement guideline is that it might not block the complex and uncertain private litigation that we are concerned about. Whether it would or not would depend on the courts, which might interpret the statute considering the enforcement guidelines, but also might not. ${ }^{103}$ If varied court rulings caused difficulty for the business

\footnotetext{
10215 U.S.C. $\S 45$ (2012).

${ }^{103}$ Courts have given weight to the $\mathrm{HHI}$ standards in the 2010 Guidelines but they have not always deferred to the judgments of the FTC and DOJ, as embodied in guidelines and legal claims they have brought.
} 
operations of institutional investors, they might prefer a formal rule to this policy. A regulation would result in greater judicial deference, and legislation the most.

Should the enforcement policy be absolute or create a rebuttable presumption? Lawyers are more comfortable with the latter approach. As we acknowledge, our policy might create some false positives; it may well be appropriate to give defendants an opportunity to rebut. Suppose, for example, a defendant can show that it is highly decentralized, with independent boards of directors and firewalls making any amount of coordination within the firm highly implausible. It may therefore be better conceptualized as many small independent funds that fall below the $1 \%$ threshold than as a single huge fund. The "no talking rule," discussed below, illustrates another possible defense.

\section{B. Diversification Effects}

The major objection to our strategy is that there could be less diversification benefit for investors. For example, investors will not be quite as well diversified with only one airline firm in their portfolio instead of four. There are two reasons that this cost is minimal.

First, if our policy did limit diversification within an industry, the size of this effect would be very small. A long literature in finance has considered how many stocks a portfolio must have to achieve effective diversification. While calculations vary depending on methodology, one highly respected study is by Campbell et al. ${ }^{104}$ The authors break major common stocks into 49 industries; industries in this definition are very broad indeed: all financial services, for example, is a single industry. They find that a randomly chosen portfolio of any 49 stocks - one from each industry - would achieve more than $90 \%$ of the available diversification (reduction in the standard deviation of a portfolio) in the market. In reality, our proposal would allow much greater diversification than this because industries would be defined more narrowly, yielding hundreds rather than dozens; institutions would be allowed to own multiple firms per industry provided they complied with the policy; an important component of variance in individual stock returns is accounted for by an industry component, so diversifying across industries is substantially better than diversifying randomly; sufficiently small institutions could fully diversify; and our proposal would not restrict diversification into firms that primarily sell in foreign countries, a form of diversification that is far under-exploited at present. ${ }^{105}$ These last two points are worth emphasizing. Most US institutional stock holdings are held by many small funds. These funds - holding less than $1 \%$ of any company - would be completely unaffected by our policy. We expect most US funds would fall into the safe harbor and make no changes to their investment strategy. Likewise, funds that invest in companies that primarily compete in other geographic markets are likely to be unaffected by our policy. Furthermore, under standard constant relative risk aversion preferences, the value of reducing the standard deviation of returns is greatest when this standard deviation is largest, so that these last units of diversification must have the lowest economic value in any case. We discuss the maximum magnitude of the welfare gain from diversification below.

Second, there is no reason why our proposal need worsen diversification even to this small extent. If savers truly want to squeeze out these last few percentage points of diversification, the

\footnotetext{
104 John Y. Campbell et. al., Have Individual Stocks Become More Volatile? An Empirical Exploration of Idiosyncratic Risk, 56 J. Fin. 1 (2001).

105 Karen K. Lewis, Why Do Stocks and Consumption Imply Such Different Gains From International Risk Sharing?, 52 J. Inter'I Econ. 1 (2000).
} 
market will create institutional investors to do so. As we discussed in Subsection I.C, it is likely that large institutional investors will each hold different firms to maximize their control over corporate governance, because it is possible that the shares of firms not held by the largest institutions will be a good value if there are any imperfections to arbitrage and because investors may wish to achieve that last bit of diversification. This would allow savers to achieve full diversification by diversifying across institutions. Since none of the institutions would know what the saver is doing, nor would all savers want this additional diversification, company management could not assume their owners held all competitors, thereby undoing the good of the policy. Investors might compare the performance of different institutional investors, which would give those institutions an incentive to promote competition. While consumers would need to engage in a small number of additional transactions to achieve this level of diversification, we think that these costs are minimal relative to the gains from our policy, particularly because the cost is bounded from above by the gains from the additional diversification which are themselves extremely small.

Another possible worry is that institutional investors may develop industry-specific expertise that facilitates their ability to evaluate and perhaps monitor firms within an industry. If they can no longer hold stakes in all the firms in the industry, some of the advantages of this expertise will be lost. However, any fund that holds $1 \%$ or less of a firm falls in our safe harbor, so this problem applies only to very large, yet industry-specific funds. We think that the increased costs of this group are likely to be small, particularly in comparison with the social benefit from restricting common ownership among direct competitors, which is large.

Notice that any uncertainty about whether to classify an industry as an oligopoly should be resolved in favor of classification because there are little incremental costs to so doing. Such a classification will cause existing institutional investors to sell shares in a few industry players, while the complementary institutional investors buy shares in those firms. The cost of this policy reduces to the cost of the consumer of having two accounts to manage, regardless of the number and size of the oligopoly markets in the economy.

The benefits of this solution are that institutional investors will hold only one large, or a few small, firms in an oligopoly and will therefore have a financial stake in their firm doing well, even if that comes at the expense of rival firms in the industry. They will exercise their corporate governance abilities to achieve better performance of their portfolio firms, not the industry. The strategic advice the institutional investor provides and the influence it has on executive compensation will reflect these goals.

\section{Corporate Governance Effects}

Another possible concern with our policy is that it might interfere with, rather than help, corporate governance. Many commentators have argued that institutional investors improve corporate governance because their large stakes in firms give them incentives to do so. ${ }^{106}$ For them, a primary argument for large-scale mutual funds over many small-scale ones is that corporate governance involves fixed information acquisition, monitoring, and control costs on which small investors are likely to free ride. A consolidated mutual fund, it is frequently argued, ${ }^{107}$ therefore has a stronger incentive to act as

\footnotetext{
106 See, e.g., Black, supra; Roe, supra.

107 See, e.g., Andrei Shleifer \& Robert W. Vishny, A Survey of Corporate Governance, 52 J. Fin. 737 (1997).
} 
an active principal for otherwise-unaccountable managers. Thus, we would not want a policy that discouraged the existence and efficiencies of large institutional investors.

However, commentators have noted that this system of institutional-investor dominance creates agency costs. In the words of Ronald Gilson and Jeffrey Gordon:

Institutional intermediaries compete and are rewarded on the basis of "relative performance" metrics that give them little incentive to engage in shareholder activism that could address shortfalls in managerial performance; such activity can improve absolute but not relative performance [of the institution]. ${ }^{108}$

In other words, if a large investor spends time and resources improving the performance of Firm $X$, the higher stock price of Firm $X$ benefits all owners of Firm $X$. Because a large institutional investor owns the same shares, including the shares of Firm $X$, as other large institutional investors, it has gained nothing relative to its competitors. If it wants to attract more investors with relatively better returns, improving corporate governance in the companies it holds is likely a bad strategy. Partial free-riding results, though the empirical findings discussed above demonstrate that institutional investors still have some important effects on governance. Nonetheless, as Gilson and Gordon observe, the dominance of institutional investors today is not likely the result of efficient reorganization of capital markets but instead of external factors generated by government policy, above all legal subsidies for private pension schemes and regulation of institutional equity investing that came in their wake. ${ }^{109}$ An unintended consequence of these legal developments was the rise of institutions that dominated ownership of major corporations while having weak incentives to develop expertise in corporate governance. ${ }^{110}$ Gilson and Gordon argue that the solution to the problem is for the law to accommodate and encourage activist investing, who target firms that are poorly managed. ${ }^{111}$ Activist investors will be motivated to obtain the rents left over by the failure of mutual funds to engage in vigorous corporate governance.

Happily, our policy accommodates this theory and improves welfare under it. Indeed, Gilson and Gordon theory basically identifies another form of the anti-competitive effect of common ownership except in the reverse direction: common ownership of firms by funds reduces the incentives of funds to compete on the quality of their corporate governance because their rivals benefit when corporate governance improves. If funds fail at corporate governance because they lack incentives due to common ownership, concentrated ownership will ameliorate the problem. Our proposal will encourage large institutional investors to shift holdings so that they have larger stakes in individual firms-for example, a large stake in GM rather than smaller stakes in GM, Ford, and Chrysler. This will increase their incentive and ability to monitor the firm in which they have a large stake. Importantly other funds may not hold a large stake in GM, but may hold Ford. For this reason, the fund can gain relative to its competitors if it improves the performance of GM through better corporate governance. By forcing institutions to

\footnotetext{
${ }^{108}$ Ronald J. Gilson \& Jeffrey N. Gordon, Agency Capitalism: Further Implications of Equity Intermediation 7 (2014); see also Ronald J. Gilson \& Jeffrey N. Gordon, The Agency Costs of Agency Capitalism: Activist Investors and the Revaluation of Governance Rights, 113 Colum. L. Rev. 863 (2013).

109 Gilson \& Gordon, Agency Capitalism, supra at 10-12.

110 Id. at 14 .

${ }^{111}$ Id. at 18.
} 
concentrate their holdings in fewer firms, our proposal will give them greater incentives to actively govern the firms in which they have ownership.

Furthermore, our proposal could change the nature of competition between mutual funds. ${ }^{112}$ That competition at present centers primarily on fees and services, rather than on the quality of investments, which are largely homogeneous across providers. ${ }^{113}$ Investment quality, if driven primarily by stock-picking, may not be a desirable dimension of competition given the (approximate) efficiency of financial markets. (Note however, that stock-picking funds, as opposed to industry-picking funds, are not disturbed by our policy since their competitive advantage is allegedly knowing which of the four airlines to hold, rather than holding all of them.) However, from the point of view of the consumer, competition in the quality of governance that institutions can supply, and therefore the profits they can generate, is a good locus of competition. If our proposal reduces the focus of institutional investors on stock picking and increases their focus on managing the firms they owned in a concentrated way to improve their performance, we would view this as a benefit not a cost. Our policy seems likely to provide additional pressure to improve governance and competition among the firms in product and labor markets.

However, it is worth noting that our proposal would fundamentally change the pattern of holdings of the largest investors in the economy and thus the basic structure of the financial sector. Institutional investors would each hold large stakes in a smaller number of firms rather than small stakes in many. This would have the benefit of making them dominant shareholders with an incentive to monitor firms, but could lead them to abuse minority shareholders. The possibility that large shareholders may harm minority shareholders is a classic challenge in corporate finance. ${ }^{114} \mathrm{~A}$ variety of corporate and securities laws aim to deal with this problem. ${ }^{115}$ While these concerns, therefore, may mitigate some of the upside benefits to our proposal on corporate governance, we do not believe they are significant enough even to outweigh these benefits, much less constitute grounds for overturning the competitive benefits of our policy.

A final related concern is that the concentrated holdings our policy would create would make it more challenging for institutions to flexibly move their holdings across different firms. For example, if Fidelity was currently holding firm $A$ in industry $X$ in a concentrated manner and it believed firm $A$ was underperforming and wished to begin holding firm B, it would first have to unload all its large (say 20\%) shareholding in A before it could acquire any shares in B. This might be a long, cumbersome and costly process given that a large sale like this could reduce the price of firm $A$ if market liquidity is imperfect. The solution to this problem is to allow institutional investors that are divesting $A$ and acquiring $B$ to have an appropriate grace period in which to accomplish the transaction. In such a limited time an

\footnotetext{
112 We tread speculatively in this paragraph. The industry is complex, fluid, and poorly understood.

${ }^{113}$ Ali Hortaçsu \& Chad Syverson, Produce Differentiation, Search Costs, and Competition in the Mutual Fund Industry, 119 Q.J. Econ. 403 (2004); John C. Coates IV \& R. Glenn Hubbard, Competition in the Mutual Fund Industry: Evidence and Implications for Policy, 33 J. Corp. L. 151 (2007).

${ }^{114}$ Rafael La Porta, Florencio Lopez-De-Silanes, Andrei Shleifer, \& Robert Vishny, Investor Protection and Corporate Governance, 58 J. Fin. 3 (2000).

115 See, e.g., Eric A. Posner \& E. Glen Weyl, Quadratic Voting as Efficient Corporate Governance, 81 U. Chicago L. Rev. 251 (2014).
} 
institutional investor will not be able to soften competition between $A$ and $B$, particularly as it is in the process of selling all its shares in A.

A more serious version of this concern is that many mutual funds have sold products to consumers, such as S\&P tracking funds, that they could not legally offer at large scale and comply with our policy. We feel this issue can be solved by announcing the enforcement policy and building in a delay between announcement and implementation. In many cases, the contracts written by institutional investors do not strictly commit them to buying any precise portfolio. ${ }^{116}$ Moreover, funds are frequently retired and new funds created, with the proceeds from liquidated funds returned to shareholders. The newly created fund would have a prospectus reflecting compliance with antitrust enforcement policies. Thus, if a transition period were announced to allow institutions to come into compliance, there should not be a problem with breaking obligations. Finally, if there were a few cases where real problems emerged, regulators such as the Securities and Exchange Commission and Consumer Financial Protection Bureau could find a solution that satisfied both competition and investor protection concerns. $^{117}$

\section{The Risk of Short-Term Disruption in Financial Markets}

A final objection to our proposal is that it would force institutional investors to sell a huge quantity of assets, which would artificially depress the share prices in the firms sold. This concern is illegitimate for several reasons. First, reduced purchases by some institutional investors would be compensated by increased purchases by other institutional investors as they reallocate their holdings into fewer firms within the oligopoly. Because of investor demand for balance across different institutional investors and because of the equilibration of efficient capital markets, this reorganization will not cause significant and non-transitory fluctuations in share prices away from their fundamental values. If it did, arbitrageurs would arrive and compete away any disequilibrium prices. Second, if this reorganization made the markets for stocks more concentrated across firms, and thus potentially increased market power or reduced liquidity in the markets for those stocks, this would encourage entry by the small institutional investors that our policy permits to remain diversified. Their entry would provide liquidity rather than corporate governance.

Third, and most important, if common ownership truly is the problem we believe it to be, then a part of the current value of the equity of publicly traded firms results from the oligopoly power created by common ownership that allows competitors to raise prices and depress wages. Weakening this oligopoly power would lower equity values to levels reflecting competition. If prices are higher than competitive levels, it is efficient and desirable for prices, profits, and therefore the value of the affected equities to decrease; this will allocate resources in the economy more efficiently. This value would not be lost. On the contrary, it would be transferred to consumers, and workers and other suppliers. Indeed, it would not just be transferred but would create additional value for consumers and workers because

\footnotetext{
${ }^{116}$ See, e.g., Vanguard 500 Index Prospectus, available at https://personal.vanguard.com/us/funds/snapshot?FundIntExt=INT\&Fundld=0540.

117 Particularly considering President Obama's Executive Order instructing agencies to consider competition concerns when regulating. Exec. Order No. 13725, Steps to Increase Competition and Better Inform Consumers and Workers to Support Continued Growth of the American Economy (April 2016).
} 
increased competition reduces the deadweight loss from monopoly power. ${ }^{118}$ Thus any decrease in equity values associated with our proposal is a lower bound on the measure of its benefit to consumers, and proves that the policy is necessary. We anticipate that some oligopoly firms will object to restrictions on common ownership by arguing that it will depress their stock prices. But this argument is tantamount to an admission that common ownership has already raised stock prices. ${ }^{119}$

\section{E. Social Welfare}

We have so far made our argument in a way that is compatible with standard legal analysis, showing that our policy would identify presumptively anticompetitive behavior, and then demonstrating that the costs of our policy-on diversification, for example-are not great enough to rebut the presumption. Here, we take a somewhat different approach deriving from welfare economics. We show that under plausible assumptions, our policy would generate large gains in social welfare and its benefits under any plausible assumptions would be several orders of magnitude greater than its costs.

The analysis that follows is extremely rough and uses many specific assumptions for highly uncertain numbers. However, we try to choose standard parameter values and err on the side of conservatism. Our conclusion is that benefits dwarf costs by so many orders of magnitude that it is implausible that any reasonable adjustment to parameter values would change our conclusion. We focus on the principal benefits and costs of our proposal: the benefits to competition and the costs to diversification.

Suppose instituting our policy reduces the $\mathrm{MHHI}$ of the industries that it affects from on average 4000 to 3100 . This assumption is reasonable as Azar, Schmalz and their co-authors find that the aggregate MHHID in banking and airlines is $1000-2000$ points and starts at 3500-5000 in local markets. The analysis in Subsection I.C. suggests our policy would eliminate $90 \%$ of this harm. To be conservative, we assume that MHHI begins at 4000 and our policy reduces it by 900 points. We then assume that the industries are characterized by a linear demand and constant marginal cost. These are conservative assumptions as they lead to quite low rates of pass-through of costs (and thus market power) into prices relative to those typically found in empirical studies. Glen Weyl and Michal Fabinger show that the passthrough rate is the leading determinant of the degree to which market power leads to transfers from consumers to producers and deadweight loss. ${ }^{120}$ We further assume that the industry has a constant (in prices, not across scenarios) "conduct parameter" (fraction of the marginal consumer surplus translated into industry mark-ups) equal to $\mathrm{HHI} / 10,000$, as would be the case in a symmetric Cournot model. ${ }^{121}$ We treat the profit of the industry prior to the policy as a benchmark for the return on capital in that industry and measure all effects relative to this benchmark. This will allow us to compare the effects on the competition side to effects on diversification.

\footnotetext{
${ }^{118}$ Reducing monopoly power and transferring surplus to consumers and workers has the additional benefit of stimulating labor supply and thus raising the revenue generated by the labor income tax.

${ }^{119}$ As Elhauge observes, lost equity value is not a defense to antitrust challenges for just this reason. See Elhauge, supra (and citations therein). We thus welcome estimates from industry participants of the decline they expect in equity values; these will be insider estimates of the anticompetitive effect of common ownership.

${ }^{120}$ E. Glen Weyl \& Michal Fabinger, Pass-Through As an Economic Tool: Principles of Incidence Under Imperfect Competition, 121 J. Pol. Econ. 528 (2013).

${ }^{121}$ See id., for further detail.
} 
In this case, when $\mathrm{MHHI}$ is 4000 , profits are $41 \%$ of maximum potential surplus, consumer surplus is $51 \%$, and deadweight loss makes up the remaining $8 \%$. When $\mathrm{MHHI}$ falls to 3100 , deadweight loss falls by $2.5 \%$ of surplus while profits fall by about $5 \%$ of potential surplus and thus consumer surplus rises by about $7.5 \%$ of potential surplus. The change in industry structure transfers about $11 \%$ of profits to consumers from firms and generates about $6 \%$ of additional pure social gain from reduced deadweight loss, all as a percent of pre-intervention profits. While there is a wide-ranging debate about how to properly weigh consumer and firm surplus, one middle-of-the-road proposal was made by Hendren, who suggested (based on estimated marginal deadweight loss of taxation) valuing profits at $77 \%$ of consumer surplus. ${ }^{122}$ Under this metric the social welfare gain from this change is $12 \%$ of ex ante firm profits. ${ }^{123}$

On the cost side, we calculated the diversification losses associated with what we consider to be the most extreme scenario for the harms created by our proposal: that it directly causes the loss of $5 \%$ of the potential diversification gains given our arguments above the almost all diversification could be achieved while following the policy. This would imply an increase in the standard deviation of portfolio returns to 0.175 from the annual standard deviation of roughly 0.15 that Campbell et al. estimate exists in an optimally diversified market portfolio. ${ }^{124}$

How costly is such added risk? If investors have constant relative risk-aversion, as is typically assumed, the cost of relative fluctuations in their wealth in units of percent increase in the expected wealth level is roughly half of the variance of their wealth multiplied by their risk-aversion coefficient. The most commonly used and widely supported risk-aversion coefficient is unity. This corresponds to investors having utility that is a logarithmic function of their wealth, as found in numerous studies. ${ }^{125}$ This implies that the loss of diversification would be worth approximately $0.41 \%$ of asset holdings in terms of consumer utility. Note that average stock returns themselves are not affected by the policy. The only cost to consumers is slightly less diversification within any one large mutual fund. A consumer that chose to hold two mutual funds managed by different corporations would experience an even smaller reduction in diversification. A consumer invested in a very small mutual fund (note that these funds comprise about $30-40 \%$ of stock market holdings) would experience zero reduction in diversification. Furthermore, many investors are in practice already imperfectly diversified. Thus $.41 \%$ is likely two or three times the actual reduction in diversification that would occur in practice.

The other potential cost associated with our proposal is any lost economies of scale, and thus increased fees on funds, resulting from the inability of funds to fully diversify under our proposal. However, such costs are almost certainly trivial or even negative; there is nothing in our proposal that limits the size of institutional investors. In fact, by providing a clear safe harbor means of staying within the law, our proposal may allow institutional investors to safely expand further. Furthermore,

\footnotetext{
122 Nathaniel Hendren, The Inequality Deflator: Interpersonal Comparisons without a Social Welfare Function, (NBER Working Paper No. 20351, July 2014).

${ }^{123}$ To get a sense of how conservative these numbers are, we tried running the same analysis in the case that the $\mathrm{MHHI}$ was reduced from 5000 to 3000 . In this case the gain was a massive $23 \%$ of profits. With higher pass-through rates (generated by more realistic demand forms or the economies of scale that exist in most oligopoly industries) this figure could be as high as $30-40 \%$ of profits.

${ }^{124}$ Campbell et al., supra.

${ }^{125}$ Raj Chetty, Interest Rates, Irreversibility, and Backward-Bending Investment, 74 Rev. Econ. Stud. 67 (2007); Betsey Stevenson \& Justin Wolfers, Economic Growth and Subjective Well-Being: Reassessing the Easterlin Paradox, Brookings Papers on Economic Activity (Spring 2008).
} 
institutional investors have grown dramatically over the last thirty years and yet fees have fallen only very modestly, by a smaller magnitude than even the diversification losses we calculate. ${ }^{126}$ If the fund industry is competitive then these fees track fund costs and are informative about economies of scale. Thus, the harms from reduced economies of scale seem extremely likely to be essentially zero and are certainly upper bounded by the costs to diversification, which are themselves tiny compared to the benefits of our proposal.

Thus, even when we estimate the gains from our proposal extremely conservatively and neglect any benefits to corporate governance, competition in the market for labor or political economy; and when we make the most pessimistic reasonable assumption about reduced diversification, the benefits of the proposal are $12 \%$ of the return on capital of affected firms, while the costs are $0.41 \%$ of those returns, a difference of 30 times. There is a distributional consequence to our policy also; the costs fall on investors, the lower prices from more competition accrue to all consumers. Thus, the policy would contribute to lowering inequality.

On net the policy is clearly beneficial. How might we measure its aggregate benefits? At present corporate profits are about 9\% of GDP per the US Bureau of Economic Analysis, the highest level (except for the last few years) since the early 1950's. ${ }^{127}$ In a 2016 survey of competition in the United States (based on 2012 data), The Economist found that $42 \%$ by revenue of 900 industries surveyed are now oligopolies in a sense somewhat looser than that we suggest (up from $28 \%$ in 1997). ${ }^{128}$ These oligopolies are almost certainly disproportionately profitable, but to be conservative, let us suppose that one quarter of these profits comes from oligopolistic industries and that those oligopolistic industries are less competitive than they would otherwise be due to common ownership by mutual funds. Our conservative net gain estimate is that about $11 \%$ of the aggregate profits in oligopolistic industries would be gained in welfare. This is equal to a quarter of a percent of GDP or roughly $\$ 50$ billion annually that would accrue to the consumers of oligopoly products. With less conservative assumptions this gain could well be many times larger and even using The Economist's strictest definition of oligopoly as a base for these gains the magnitude would be $\$ 10$ billion.

The bottom line is that our modest policy would generate enormous social gains by reducing anticompetitive behavior while causing only trivial losses in diversification, and very likely improving corporate governance. Indeed, the formal quantitative welfare analysis indicates that a stricter policy would be justified by the social gains. However, we think now it would make sense to start with a more modest policy since even a modest policy requires adjustments as the investment fund industry reorganizes itself and agencies and courts become accustomed to enforcing it.

The principle behind our proposal is that it is easier to rearrange financial holdings than it is to change the organization of real assets. The efficiency of the US economy is not advanced if the rise of institutional investors blocks the ability of manufacturers of, for example, washing machines to combine to achieve economies of scale. There is no realistic alternative to achieving those real gains other than a

\footnotetext{
${ }^{126}$ Kenneth French, Presidential Address: The Cost of Activist Investing (2008).

127 Our source is the Federal Reserve Bank of St. Louis economic data series: corporate profits after tax (https://fred.stlouisfed.org/series/CP) and GDP (https://fred.stlouisfed.org/series/GDP).

128 Too Much of a Good Thing, The Economist (March 26, 2016), available at http://www.economist.com/news/briefing/21695385-profits-are-too-high-america-needs-giant-dose-competitiontoo-much-good-thing.
} 
combination of real assets. By contrast, rearranging the financial claims on those assets into different institutional investors costs very little and may have significant ancillary corporate governance benefits. Under our proposal, when market shares change due to a merger, institutional investors will automatically adjust their holdings in response and thereby minimize anticompetitive effects. Under our approach the agencies can conduct merger reviews as they normally do, by weighing efficiencies and competition between product market competitors, without regard to which mutual funds might be holding what share of which merging party. ${ }^{129}$

\section{Alternative Approaches}

We briefly consider some alternative approaches to our proposed policy. While we think they are inferior, they are worth considering.

\section{A. Purely Passive Investing}

The first alternative might be loosely described as the "purely passive" index fund solution. The SEC and the antitrust agencies can make it clear to institutional investors that they are required to be strictly "passive" (in the antitrust sense) investors if they accumulate large amounts of stock. ${ }^{130}$ An institutional investor could be allowed to own as much equity as it wants-within industries as well as across industries - as long as it a) never communicates with the operational firms, b) commits itself to "mirror voting," in which it votes the same as other shareholders do, and c) commits to a clear, verifiable investment strategy such as indexing that allows the investor no discretion in selling some stocks and buying others that could be used to punish firms that choose strategies against its wishes. Any institutional investor wishing to exercise this option would have to commit to it over the full institution, as otherwise the corporate governance incentives of the not strictly passive parts of the institution would have the incentive to limit competition

This sort of approach is not unknown in current law. Under the Hart-Scott-Rodino (HSR) Act, parties who merge with or acquire large stakes in firms must notify the FTC and Department of Justice unless, in the case of acquisitions, they are made "solely for the purpose of investment." ${ }^{131}$ In a recent settlement, ${ }^{132}$ the Justice Department and ValueAct agreed that the passive investor exception does not

\footnotetext{
${ }^{129}$ This is yet another major benefit of our approach. Under existing practice, the DOJ and FTC in principle take (or should take) account the effect of a potential operational merger on ability of existing institutional investors to cause anticompetitive conduct through their influence on their holdings of the merging firms. This would be unnecessary under our approach.

${ }^{130}$ The SEC has extensive power to regulate communications among shareholders and between shareholders and management. See 15 U.S.C. § 78n(a) (2012). There are discussions in the literature on the impact of these rules on corporate governance efforts by institutional investors. See, e.g., Norma M. Sharara \& Anne E. Hoke-Witherspoon, The Evolution of the 1992 Shareholder Communication Proxy Rules and Their Impact on Corporate Governance, 49 Bus. Law. 327 (1993).

13115 U.S.C. § $18 \mathrm{a}(\mathrm{c})(9)(2012)$.

${ }^{132}$ For a discussion, see Barry A. Nigro, Jr., ValueAct Settlement: A Record Fine for HSR Violation (2016), https://corpgov.law.harvard.edu/2016/07/19/valueact-settlement-a-record-fine-for-hsr-violation/\#5.
} 
apply when the investor intends to communicate with an issuer's officers or directors about potential mergers, changes in corporate structure, pricing strategies, and other major business decisions. ${ }^{133}$

The pure passivity option, if properly enforced, would prevent index fund institutional investors from causing anticompetitive harm. As the O'Brien \& Salop model makes clear, institutional investors can affect competitive outcomes only by exercising control over operational firms, and control requires communication and voting or the ability to sell the shares of the firm. Index funds, as normally understood, cannot fail to hold the companies in the index. As a result, our proposed safe harbor would include institutional investors of an arbitrary size so long as all funds they control are index funds and purely passive.

However, we have three concerns with the purely passive option that make us skeptical it will be widely used. First, it is only a useful or meaningful option for index funds and exchange traded funds, as other funds pursue more active strategies that could not comply with strict passivity. However, these funds only constitute a small fraction of the total institutional investing market, likely in the range of 15$20 \%{ }^{134}$ As a result the potential pool of institutional investors eligible for this option is a small fraction of the total. Second, nearly all institutional investors who offer index funds also manage some active funds which they would have to divest or split into separate institutions to comply with the safe harbor. This is likely to be cumbersome for most institutional investors. A divested index fund would be likely to fall under our $1 \%$ safe harbor, making the super passive safe harbor redundant. Current regulations require institutional investors to carry out their fiduciary duty on behalf of the investor; ${ }^{135}$ and this rule would have to be interpreted to allow an index fund to be a responsible fiduciary by foregoing corporate governance in exchange for low costs and avoidance of litigation, both of which are beneficial to clients. Finally, as we highlighted above, the marginal diversification gains from strict indexing are so small relative to those that comply with our policies that we suspect other factors (the desire to engage in corporate governance, to fully harness economies of scale, etc.) would dominate.

As a result we believe that few investors are likely to use this option. However, by including it, our policy preserves the ability of consumers to choose to use lowest-cost investing option available to them.

\section{B. Fewer Mergers}

Another solution we have heard proposed is to tighten merger review considering the common ownership that the agencies expect to see. ${ }^{136}$ Many industries are already oligopolies, and tightening merger control going forward will do nothing to make existing oligopolies more competitive. Moreover, some industries form as oligopolies initially and do not go through a consolidation phase. For example, Facebook and Myspace competed and Myspace exited, but neither one merged with any significant competitor. Thus, the competition regulator had no chance to affect industry structure by blocking mergers that created the oligopoly. Third, and most important, mergers can be efficient. If two firms

\footnotetext{
133 U.S. v. VA Partners I, LLC, et al., Case No. 16-cv-01672 (WHA), Proposed Final Judgement, p. 4, available at https://www.justice.gov/atr/file/874761/download.

${ }^{134}$ See supra.

${ }^{135}$ See Department of Labor, Interpretive Bulletin Relating to Written Statements of Investment Policy, Including Proxy Voting Guidelines, 29 CFR 2509.94-2 (2001); Securities and Exchange Commission, Proxy Voting by Investment Advisers, 17 CFR Part 275 (2003), https://www.sec.gov/rules/final/ia-2106.htm\#ruletext.

${ }^{136}$ For a discussion, see Herbert J. Hovenkamp, Antitrust and Efficient Mergers (unpub., 2016).
} 
combine complementary assets, or lower costs, or undertake some other efficient actions, that action can benefit consumers. It will be costly for efficiency in the economy to adopt a policy that disallows mergers because in the future a common mutual fund might invest in that industry. Engaging in merger control, likewise, that could block an otherwise procompetitive merger because an institutional investor owned shares in both parties would be detrimental to economic efficiency.

Finally, merger control cannot address the concerns we have raised: that common ownership effectively already leads to all the anticompetitive effects of a merger without the procompetitive economies of scale. Thus, a merger, starting from substantial common ownership, may often be desirable (unless the common ownership problem can be solved). Thus, greater merger control without directly addressing common ownership would have little effect and potentially even be counterproductive.

The benefit of this policy is that when an industry is fragmented, common ownership by institutional investors produces minimal anticompetitive harm. However, only a fraction of the economy falls in the fragmented category. Moreover, the cost to operational efficiency and the transition cost would be significant; given such a speculative benefit, the policy is inadvisable.

\section{Conclusion}

If historical trends continue, a handful of gigantic institutional investors will one day share control of product markets in dozens of oligopolistic industries. Even those who are skeptical of the findings of Azar and his coauthors should give some thought about the potential dangers of this state of affairs. Economic theory provides us with a good understanding of the incentives of such investors and corporate governance regulations give them ability to act on their incentives. The social problem created by current common ownership of equities by institutional investors, and expected growth in that ownership, requires a forward-looking, rational policy response-as illustrated by the Clayton Act itself, which adopts a prophylactic approach that does not require proof of competitive harm but states that the risk alone justifies liability.

We argue that a simple solution would work best: no institutional investor invested in more than a single (effective) firm in an oligopoly may own more than $1 \%$ of the industry or communicate with its managers. This would induce most significant institutions to hold only a single effective firm and would restore oligopolistic markets to competitive conditions.

This solution is pragmatic and conservative in several senses. First, this use of the Clayton Act is one intended by the original authors of the law; it is in no way innovative. Second, our policy disallows only behavior that is clearly illegal under the Clayton Act and thus should be straightforward for the enforcement agencies to pursue in court. Third, the policy has essentially no offsetting costs as it is unlikely to reduce opportunities for diversification to any significant extent, and brings substantial ancillary corporate governance benefits. And fourth, it requires only financial reorganization of shareholdings of firms and no actual changes in the patterns of real asset control within firms in a manner that could harm operational efficiency.

We propose such a conservative reform because it is often desirable to attack a problem gradually, eliminating the clearest forms of harm, to allow evidence on a reform's efficacy and effects to 
accumulate before strengthening it. However, it may well turn out our proposal is insufficiently aggressive for at least two reasons.

First, there is a strong interactive effect of different mutual funds all having similar holding patterns which would not be caught by our policy. If the effect of our policy were to fragment the mutual fund industry into hundreds of institutions, all below the $1 \%$ threshold and all holding a fully diversified portfolio, we would be concerned that the harmful patterns at present could be replicated even if their effects were somewhat mitigated. Similarly if we are incorrect in our prediction that few institutions would choose the "pure passivity" policy and this became a dominant stance for institutional investors, we would be concerned about the implications this could have for the structure of the finance industry and corporate governance. In that case, the $1 \%$ threshold might need to be changed to a lower threshold and/or the pure passivity safe harbor altered. We are optimistic that institutions will invest in single competitors at a high enough level that this case will not arise, but we do not know for sure what will happen.

Second, we were conservative in defining the level at which structural presumptions arise relative to standard practice. Many industries with $\mathrm{HHI}$ below 2500 may be of competitive concern, even if they are not automatically assumed to be, and many holding patterns that increase MHHI by less than 200 may be harmful. Under our policy, this problem could easily be addressed over time by the FTC and DOJ, which would gradually designate more industries as oligopolies as appropriate.

A final, more challenging issue is one that is likely to arise precisely if our proposal is successful. This is that, once institutional investors have concentrated their holdings, there may still be a small number of them controlling competing families of firms. Anticompetitive behavior between such investment conglomerates would have to be carefully policed, just as in countries like Korea and Japan where they are common. 
Appendix ${ }^{137}$

\begin{tabular}{|c|c|c|c|c|}
\hline Industry & HHI & Key competitors & Top 5 shareholders & $\begin{array}{l}\text { Ownership } \\
\text { stake }\end{array}$ \\
\hline \multirow{21}{*}{ Mobile phones } & \multirow{20}{*}{2,852} & \multirow{5}{*}{ AT\&T } & Vanguard & $6.24 \%$ \\
\hline & & & BlackRock & $4.36 \%$ \\
\hline & & & State Street & $4.12 \%$ \\
\hline & & & Evercore & $3.29 \%$ \\
\hline & & & Capital Group & $2.16 \%$ \\
\hline & & \multirow{5}{*}{ Verizon } & Capital Group & $6.95 \%$ \\
\hline & & & Vanguard & $6.30 \%$ \\
\hline & & & BlackRock & $5.00 \%$ \\
\hline & & & State Street & $3.85 \%$ \\
\hline & & & Wellington & $1.69 \%$ \\
\hline & & \multirow{5}{*}{ T-Mobile } & Deutsche Telekom & $65.06 \%$ \\
\hline & & & T. Rowe Price & $4.69 \%$ \\
\hline & & & Fidelity & $2.01 \%$ \\
\hline & & & JP Morgan & $1.88 \%$ \\
\hline & & & Vanguard & $1.71 \%$ \\
\hline & & \multirow{5}{*}{ Sprint } & SoftBank & $82.73 \%$ \\
\hline & & & Doge \& Cox & $4.63 \%$ \\
\hline & & & Discovery & $1.01 \%$ \\
\hline & & & BlackRock & $0.97 \%$ \\
\hline & & & Vanguard & $0.96 \%$ \\
\hline & 2,878 & General Mills & Vanguard & $7.15 \%$ \\
\hline
\end{tabular}

137 Sources:

- Fund holdings from Thomson ONE database of $13 \mathrm{~F}$ filings.

- Mobile phone market shares calculated based on Q2 2016 revenues reported by Fierce Wireless, "How Verizon AT\&T, T-Mobile, Sprint, and more stacked up in Q2 2016" (August 15, 2016), accessible at http://www.fiercewireless.com/wireless/how-verizon-at-t-t-mobile-sprint-and-more-stacked-up-q22016-top-7-carriers.

- Breakfast cereal market shares from Euromonitor, "Breakfast Cereals in the US" (October 2015)

- Soft drinks market shares from Statista, "Soft drink market share in the US from 2004 to 2015" (2015), accessible at https://www.statista.com/statistics/225464/market-share-of-leading-soft-drink-companiesin-the-us-since-2004/.

- Airlines market shares from US v. US Airways Group and AMR Corporation complaint, which calculated HHIs of over 2,500 in hundreds of city-pair markets.

- Aluminum market shares from US International Trade Commission, "Unwrought Aluminum: Industry \& Trade Summary" (March 2010), accessible at https://www.usitc.gov/publications/332/ITS 6.pdf.

- Cooking stove market shares from US v. AB Electrolux et al. complaint and DOJ, "GE and Electrolux Walk Away from Anticompetitive Cooking Appliance Merger Before Four-Week Trial Ends" (2016), accessible at https://www.justice.gov/atr/division-operations/division-update-2016/ge-electrolux-walk-awayanticompetitive-appliance-merger. 


\begin{tabular}{|c|c|c|c|c|}
\hline \multirow{19}{*}{$\begin{array}{c}\text { Breakfast } \\
\text { cereal }\end{array}$} & & & BlackRock & $6.08 \%$ \\
\hline & & & State Street & $6.06 \%$ \\
\hline & & & MFS Investment Mgmt & $3.02 \%$ \\
\hline & & & Capital Group & $2.13 \%$ \\
\hline & & \multirow{5}{*}{ Kellogg } & Kellogg Foundation Trust & $19.62 \%$ \\
\hline & & & KeyBanc Capital Markets & $7.53 \%$ \\
\hline & & & Vanguard & $5.09 \%$ \\
\hline & & & BlackRock & $4.15 \%$ \\
\hline & & & Capital Group & $3.38 \%$ \\
\hline & & \multirow{5}{*}{$\begin{array}{l}\text { Pepsi (owns } \\
\text { Quaker Oats) }\end{array}$} & Vanguard & $7.01 \%$ \\
\hline & & & BlackRock & $4.69 \%$ \\
\hline & & & State Street & $3.95 \%$ \\
\hline & & & Wellington & $1.87 \%$ \\
\hline & & & Bank of America Merrill Lynch & $1.62 \%$ \\
\hline & & \multirow{5}{*}{ Post } & Wellington & $9.65 \%$ \\
\hline & & & Vanguard & $6.94 \%$ \\
\hline & & & BlackRock & $6.89 \%$ \\
\hline & & & Fidelity & $6.29 \%$ \\
\hline & & & Dimensional & $5.55 \%$ \\
\hline \multirow{15}{*}{ Soft drinks } & \multirow{15}{*}{2,860} & \multirow{5}{*}{ Coke } & Berkshire Hathaway & $9.27 \%$ \\
\hline & & & Vanguard & $6.35 \%$ \\
\hline & & & Capital Group & $6.17 \%$ \\
\hline & & & BlackRock & $4.37 \%$ \\
\hline & & & State Street & $3.83 \%$ \\
\hline & & \multirow{5}{*}{ Pepsi } & Vanguard & $7.01 \%$ \\
\hline & & & BlackRock & $4.69 \%$ \\
\hline & & & State Street & $3.95 \%$ \\
\hline & & & Wellington & $1.87 \%$ \\
\hline & & & Bank of America Merrill Lynch & $1.62 \%$ \\
\hline & & \multirow{5}{*}{ Dr. Pepper } & Vanguard & $9.23 \%$ \\
\hline & & & BlackRock & $6.97 \%$ \\
\hline & & & State Street & $4.42 \%$ \\
\hline & & & JP Morgan & $3.56 \%$ \\
\hline & & & Fidelity & $1.86 \%$ \\
\hline \multirow{5}{*}{ Airlines } & \multirow{5}{*}{$>2,500 * *$} & \multirow{5}{*}{ Delta } & Vanguard & $6.12 \%$ \\
\hline & & & JP Morgan & $5.17 \%$ \\
\hline & & & BlackRock & $4.48 \%$ \\
\hline & & & Lansdowne Partners & $3.54 \%$ \\
\hline & & & State Street & $3.42 \%$ \\
\hline
\end{tabular}




\begin{tabular}{|c|c|c|c|c|}
\hline & & & T. Rowe Price & $15.71 \%$ \\
\hline & & & PRIMECAP & $6.69 \%$ \\
\hline & & American & Vanguard & $6.32 \%$ \\
\hline & & & BlackRock & $5.05 \%$ \\
\hline & & & State Street & $3.53 \%$ \\
\hline & & & Vanguard & $7.19 \%$ \\
\hline & & & PRIMECAP & $6.08 \%$ \\
\hline & & United & BlackRock & $5.94 \%$ \\
\hline & & & PAR Capital & $5.05 \%$ \\
\hline & & & JP Morgan & $4.18 \%$ \\
\hline & & & PRIMECAP & $11.83 \%$ \\
\hline & & & Fidelity & $7.84 \%$ \\
\hline & & Southwest & Vanguard & $6.25 \%$ \\
\hline & & & BlackRock & $5.42 \%$ \\
\hline & & & State Street & $3.61 \%$ \\
\hline & & & Vanguard & $8.31 \%$ \\
\hline & & & BlackRock & $7.04 \%$ \\
\hline & & JetBlue & Fidelity & $6.74 \%$ \\
\hline & & & PRIMECAP & $6.19 \%$ \\
\hline & & & State Street & $2.63 \%$ \\
\hline & & & Vanguard & $9.48 \%$ \\
\hline & & & T. Rowe Price & $7.91 \%$ \\
\hline & & Alaska & PRIMECAP & $6.12 \%$ \\
\hline & & & BlackRock & $4.57 \%$ \\
\hline & & & PAR Capital & $3.70 \%$ \\
\hline & & & Vanguard & $9.01 \%$ \\
\hline & & & Elliott Management Corp & $5.90 \%$ \\
\hline & & Alcoa & BlackRock & $4.90 \%$ \\
\hline & & & First Pacific Advisors & $4.90 \%$ \\
\hline Aluminum & 2050 & & State Street & $4.53 \%$ \\
\hline Aluminum & 3,058 & & Dimensional & $8.49 \%$ \\
\hline & & & BlackRock & $5.43 \%$ \\
\hline & & $\begin{array}{l}\text { Century } \\
\text { Aluminum }\end{array}$ & Vanguard & $4.80 \%$ \\
\hline & & & Victory Capital & $2.54 \%$ \\
\hline & & & D. E. Shaw & $1.88 \%$ \\
\hline & & & Vanguard & $6.42 \%$ \\
\hline Cooling ctove & 2661 & $G$ & BlackRock & $5.85 \%$ \\
\hline CookIng stoves & 2,661 & Gt & State Street & $3.94 \%$ \\
\hline & & & Capital Group & $3.02 \%$ \\
\hline
\end{tabular}




\begin{tabular}{|l|l|lr|} 
& & Fidelity & $1.96 \%$ \\
\cline { 3 - 4 } & & Vanguard & $8.94 \%$ \\
& & BlackRock & $6.49 \%$ \\
& & & $4.64 \%$ \\
& & & $3.48 \%$ \\
& & State Street & $2.82 \%$ \\
\hline
\end{tabular}

* Does not include store brands. With store brands (25\% of the market), HHI drops below 2,000.

** Based on market shares in city-pairs

Table includes holdings of foreign investors 